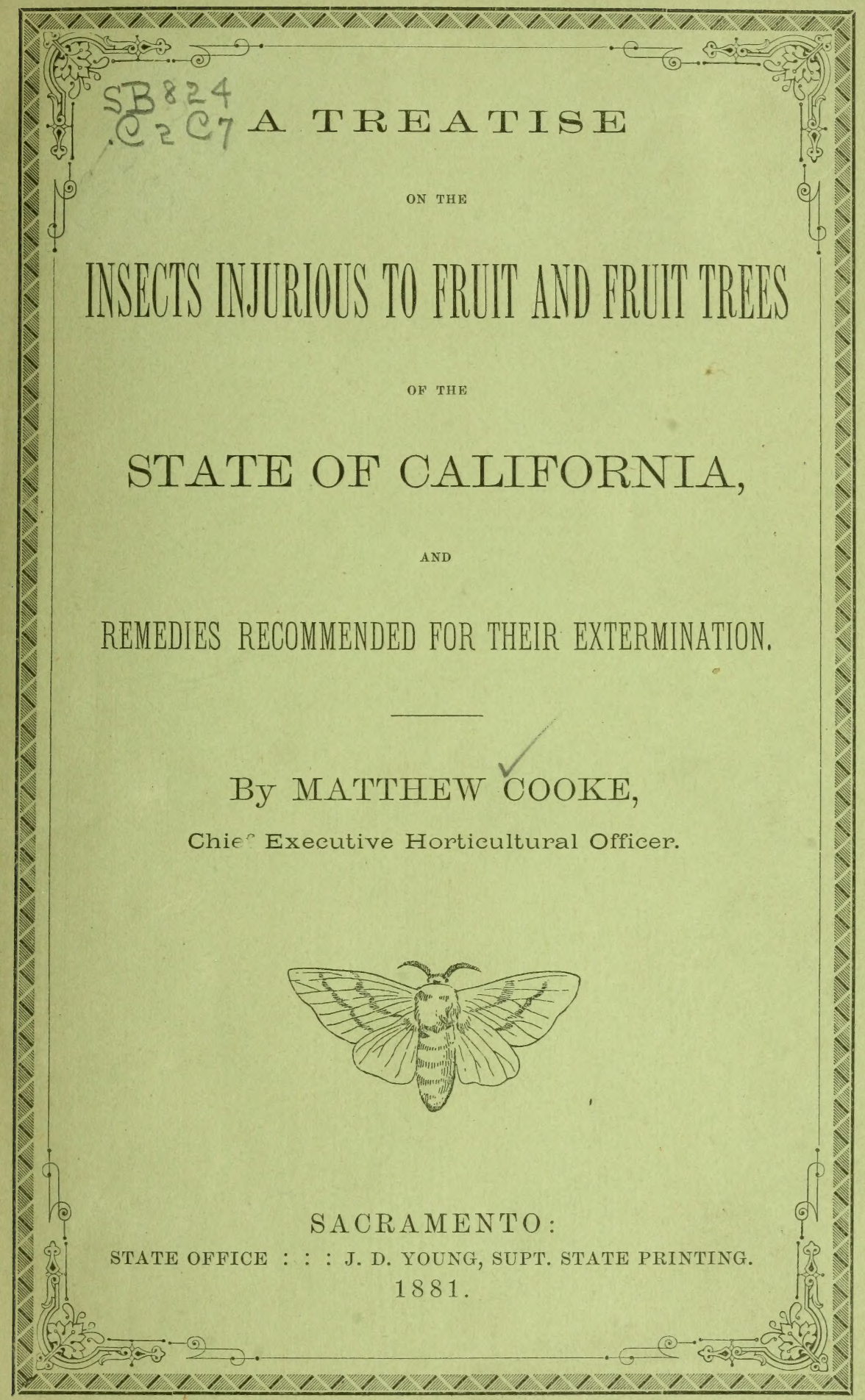





\section{-A TREATISE}

ON THE

\section{INSECTS INJURIOUS TO FRLIT' AND FRIIT' TREES}

OF THE

\section{STATE OF CALIFORNIA,}

\section{Califormia shat off.}

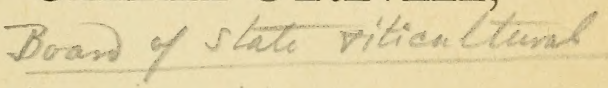

AND REMEDIES RECOMMENDED FOR THEIR EXTERMINATION.

\section{By MATTHEW COOKE,}

Chief Executive Horticultural Officer.

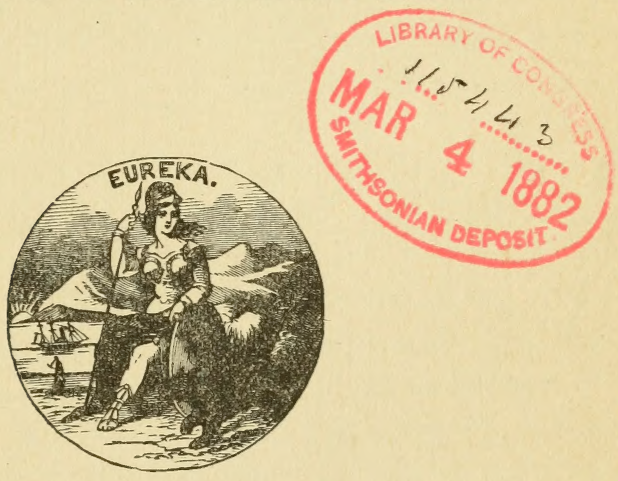

SACRAMENTO :

STATE OFFICE : : : J. D. YOUNG, SUPT. STATE PRINTING. 
SB824 


\section{PREFACE.}

To the Fruit Growers of California, and all whom it may concern:

At a meeting of the State Board of Horticultural Commissioners, held on the thirtieth day of June, eighteen hundred and eighty-one, the following resolution was unanimously adopted:

Resolved, That the Chief Executive Horticultural Officer be requested to prepare for publication, in pamphlet form, a brief, popular treatise on the more prominent insects, injurious to fruit and fruit trees; giving a description of their appearances, life, history, and the best means for their destruction.

In compliance with the above request, this work is presented for your consideration. A careful reading is respectfully solicited. The object wished to be attained is to call your attention to the dangers that are threatening the fruit growing industry of California by the spread of insects injurious to fruit and fruit trees, viz.: Codlin Moth, Scale Insects, Red Spider (Mite), Caterpillars, Saw-flies, Pear Slug, Borers, A phides, etc.; and to the laws passed for the protection of the horticultural and viticultural interests of the State, and, especially, to the remedies recommended for the extermination of said insect pests.

In writing this work we are under special obligations to Mr. C. H. Dwinelle, of the University of California, and Prof. J. Henry Comstock, Department of Entomology, Cornell University, Ithaca, New York, for kind assistance. To Doctor A. S. Packard, of Providence, Rhode Island, for furnishing fourteen of the cuts. To Massachusetts Board of Agriculture, for use of reports, and to Messrs. Chapin and Vestal, San José, for use of report. To Messrs. M. Schmidt \& Co., San Francisco, for the faithful manner in which they executed the cuts, and especially to their artist, Mr. Buchi, who made the sketches from nature.

Respectfully,

MATTHEW COOKE, Chief Executive Horticultural and Health Officer. 



\section{OFFICERS AND MEMBERS}

\section{OF THE \\ State Board of Viticultural Commissioners.}

ARPAD HARASZTHY, President San Francisco.

Commissioner for the San Francisco District.

CHAS. A. WETMORE, Vice President San Francisco.

Commissioner for the State at Large.

CHAS. KRUG, Treasurer St. Helena, Napa County.

Commissioner for the Napa District.

J. DeBARTH SHORB San Gabriel, Los Angeles County.

Commissioner for the State at Large.

ISAAC DETURK Santa Rosa, Sonoma County.

Commissioner for the Sonoma District.

R. B. BLOWERS Woodland, Yolo County.

Commissioner for the Sacramento District.

GEO. WEST Stockton, San Joaquin County.

Commissioner for the San Joaquin District.

L. J. ROSE San Gabriel, Los Angeles County.

Commissioner for the Los Angeles District.

G. G. BLANCHARD Placerville, El Dorado County.

Commissioner for the El Dorado District.

\section{JOHN H. WHEELER, Secretary.}

CHAS. A. WETMORE, Chief Executive Viticultural and Health Officer.

MATTHEW COOKE,

Chief Executive Horticultural Officer.

OFFICE OF THE BOARD:

No. 111 Leidesdorff Street, San Francisco, Cal. 


\section{OFFICERS AND MEMBERS}

OF THE

\section{State Board of Horticultural Commissioners.}

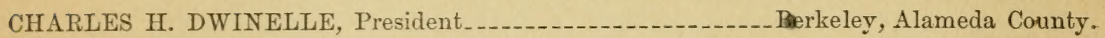
Commissioner for the State at Large.

W. W. SMITH -Vacaville, Solano County.

Commissioner for the Napa District.

M. T. BREWER Sacramento.

Commissioner for the Sacramento District.

W. B. WEST Stockton, San Joaquin County. Commissioner for the San Joaquin District.

FELIX GILLET Nevada, Nevada County. Commissioner for the El Dorado District.

ALBERT S. WHITE Riverside, San Bernardino County. Commissioner for the Los Angeles District.

Dr. S. F. CHAPIN San José, Santa Clara County. Commissioner for the San Francisco District.

A. CADWELL -Petaluma, Sonoma Cuunty.

Commissioner for the Sonoma District.

MATTHEW COOKE Sacramento.

Commissioner for the State at Large.

ELLWOOD COOPER Santa Barbara, Santa Barbara County. Commissioner for the State at Large.

CHARLES H. SHINN San Francisco.

Commissioner for the State at Large.

JOHN H. WHEELER, Secretary. Offices of the Board:

No. 111 Leidesdorff Street, San Francisco.

MATTHEW COOKE. Office, Front and M Streets, Sacramento. Chief Executive Horticultural and Health Officer.

\section{STANDING COMMITTEES}

ON THE OCCURRENCES AND RAVAGES OF AND REMEDIES AGAINST INSECT PESTS:

ALBERT S. WHITE On Citrus Trees. ELLWOOD COOPER On Olive Trees. S. F. CHAPIN MATTHEW COOKE AND FELIX GILLET On the Codlin Moth. W. B. WEST On Red Spider, Mites, etc. W. W. SMITH AND W. B. WEST -On Fruit Packages. CHARLES H. SHINN AND MATTHEW COOKE CHARLES H. DWINELLE On Transportation and Quarantine. M. T. BREWER - On Rules and Regulations. FELIX GILLET -On Conference with Shippers and Commission Merchants. - On Borers Injurious to Fruit and Fruit Trees. 


\section{BOARD OF COMMISSIONERS.}

Up to the date of this publication, County Boards of Horticultural Commissioners have been appointed as follows, authorized by an Act entitled "An Act to protect and promote the horticultural interests of the State," approved March 14, 1881:

Sacramento County-John Cox, Sutterville; Albert Halen, Folsom : Charles W. Gammon, Richland.

Yolo County-James B. Saul, Davisville; James Bullock, Woodland; I. N. Hoag, Washington.

Solano County-A. T. Hatch, Cordelia; W. W. Smith, Vacaville; W. P. Durbin, Green Valley.

Santa Barbara County-Henry Cooper, Ellwood; O. N. Cadwell, Carpenteria; E. H. Heacock, Lompoc.

El Dorado County-M. S. Robinson, El Dorado; P. J. Isbell; Placerville; P. D. Brown, Pilot Hill.

San Bernardino County-Dr. S. R. Magee, Riverside; S. E. A. Palmer, S. D. Roberts, San Bernardino.

Santa Clara County-Dr. S. F. Chapin, D. C. Vestal, San Jose; Horace Wilson, Gilroy.

Santa Cruz County-Dr. C. L. Anderson, Blakey Pilkinton, Samuel Drennan, Santa Cruz.

San Joaquin County-W. B. West, Stockton; James Crozier, Ezra Fisk, $\longrightarrow$.

Amador County-R. M. Ford, Plymouth; S. S. Hartman, Jackson, J. W. Violet, Ione.

Contra Costa County-Dr. John Strenzel, Martinez; P. F. Smith, Concord; Averett Howard, Antioch.

Nevada County - Felix Gillet, Nevada City; Charles Barker, Grass Valley; H. L. Hatch, Rough and Ready.

Placer County-Herndon Barrett, Lincoln; George W. Applegate, Clipper Gap; N. R. Peck, Ophir.

San Diego County-J. M. Asher, W. C. Kimball, and O. S. Chapin. Alameda County-A. D. Pryal, North Temescal; G. P. Crane, and Martin Mendelhall.

County Boards of Horticultural Commissioners should be appointed in the following counties: Alameda, Tuolumne, Calaveras, Marin, Sonoma, Butte, Yuba, Sutter, Los Angeles, Napa, San Diego, Tulare, Fresno, Mariposa, and Colusa.

In case the fruit growers neglect to have a Board of Horticultural Commissioners appointed in their respective counties, it will be the duty of the Chief Executive Horticultural Officerr to appoint local Inspectors to enforce such quarantine rules and regulations as approved by the State Board of Viticultural Commissioners, and authorized by sections three and four of an Act entitled "An Act to define and enlarge the duties and powers of the Board of State Viticultural Commissioners, and to authorize the appointment of certain officers to and protect the interests of Horticulture and Viticulture," approved March 4, 1881. 


\section{ACTS OF THE LEGISLATURE.}

\section{$\mathrm{AN}$ A C T}

To defing and enlarge the duties and powers of the Board of State Viticulitural CommisSIONERS, AND TO AUTHORIZE THE APPOINTMENT OF CERTAIN OFFICERS, AND TO PROTECT THE INTERESTS OF HORTICULTURE AND VITICULTURE.

\section{[Approved March 4, 1881.]}

\section{The People of the State of California, represented in Senate and Assembly, do enact as follows:}

Section 1. The Board of State Viticultural Commissioners, in addition to the duties and powers provided for by the Act entitled "An Act for the promotion of viticultural industries of the State," approved April 15, 1880, shall, in respect to diseases of grape vines and vine pests, constitute a Board of Health. It shall, in addition to laboratory work, cause practical experiments to be made to determine or demonstrate the utility of known and new remedies against such diseases and pests.

SEC. 2. The Board shall elect of their own number, or appoint from without their number, a competent person to serve as Chief Executive Viticultural Officer, who shall perform also the duties of Viticultural Health Officer, under direction of said Board, and sibject to removal from such office at any time by the Board.

SEc. 3. The Viticultural Health Officer shall have power, subject to the approval of the Board, to prevent the spread of vine diseases and vine pests, by declaring and enforcing rules and regulations in the nature of quarantine, to govern the manner of, restrain, or prohibit the importation into the State, and the distribution and disposal within the State, of all vines, vine cuttings, debris of vineyards, empty fruit boxes, or other material, on, or by which the contagion of vine diseases and germs of vine pests may be introduced into the State, or transported from place to place within the State; to declare and enforce regulations approved by the Board for the disinfection of vines, vine cuttings, vineyard debris, empty fruit boxes, and other suspected material dangerous to vineyards, while in transit, or about to be distributed, or transported into, or within the State; to classify the vineyards and viticultural regions of the State, according to the degree of health, or vine disease prevailing therein, and to change the same as circumstances may require to be done, subjecting each class to such varying rules and regulations, respecting the introduction or transportation of vines, vine cuttings, and other material liable to spread contagion of disease among vines, as may, in the opinion of the Board, become necessary and expedient for the preservation of vineyards. Such rules and regulations shall be circulated in printed form by the Board among the vine growers and fruit dealers of the State, shall be published at least thirty days in two daily newspapers of general circulation in the State, not of the same city or county, and shall be posted in a conspicuous place at the county seat of each county affected by their provisions.

Sec. 4. The Viticultural Health Officer may appoint local resident Inspectors in any and all of the viticultural regions of the State, whose duties shall be to report to him concerning the health of grapevines, the progress of vine diseases and pests, and all violations of the rules and regulations of the Board; to certify to the proper disinfection of vines, vine euttings, empty fruit boxes, and other transportable articles required by the Board to be disinfected before transportation, or while in transit, or after delivery at any point of destination; the methods of disinfection to be determined and approved by the Health Officer and the Board; to seize upon and destroy all vines, vine cuttings, debris of vineyards, empty fruit boxes, and other material liable to spread contagion, which may be found in transit, or delivered after transportation, not certified to as required by the Board; provided, that the same may be exempt from such destruction if the cost of disinfection by such Inspector shall be provided for by the owner or agent in charge thereof, as may be prescribed for such cases of negligence, carelessness, or violation of quarantine rules, and to keep a record of all proceedings as such Inspectors; provided, that there shall be no compensation for such services of inspection, excepting a fee, not to exceed one dollar for each certificate of disinfection, in case of compliance with quarantine regulations, and not to exceed five dollars for each certificate of disinfection after seizure for non-compliance; provided, however, such inspection may be employed at the option of the owners of property requiring disinfection to disinfect the same. All vines, or other articles absolutely prohibited of importation or transportation, may be promptly destroyed by any Inspector discovering the same transported or in transit, in violation of regulations, and the cost 
of such seizure, together with a fee of ten dollars, shall be paid to such Inspector out of any fine that may be collected from the party or parties guilty of such violation. Willful violation of the quarantine regulations of the Board shall be considered a misdemeanor, and punishable by a fine of not less than tiventy-five not more than one hundred dollars. Whenever required for the convenience of vine or fruit growers, or fruit dealers, a resident Inspector shall be appointed upon petition of any three neighboring vine or fruit growers, or dealers in grapes, to reside in their vicinity, if not already provided for; and there shall be not less than two Inspectors appointed for each county which is subjected to such quarantine regulations, and they shall each be subject to removal at the will of the Viticultural Health Officer, if incompetent, or if they fail to perform their duties, or are unreasonably distasteful to vine growers and grape dealers.

SEc. 5. It shall be also the duty of the Chief Executive Viticultural Officer to personally visit, examine, and report upon the several viticultural regions of the State; to prepare documents for publication, as required by the Board, relating to any and all branches of viticultural industry, including treatises for the instruction of the public; to supervise the preparation of reports for publication, and especially report upon the practicability and means of eradicating diseases from vineyards, and to superintend experiments with known and new remedies.

SEC. 6. All printing heretofore ordered by the Board shall be paid for out of the appropriations heretofore made for its use. All printing required hereafter shall be done by the State Printer.

SEc. 7. The salary of the Chief Executive Viticultural Officer shall be fixed by the Board, not to exceed one hundred and fifty dollars per month, for services while engaged as such officer, and his actual traveling expenses shall be allowed, not to exceed five hundred dollars per annum.

SEC. 8. The Board of State Viticultural Commissioners shall also appoint an officer, who shall be especially qualified, by practical experience in horticulture, for the duties of his office, to perform similar duties respecting the protection of fruit and fruit trees as are provided for in this Act in reference to grapevines, with like powers; and the salary and traveling expenses of such officer shall be fixed by the said Board at the same amounts provided for in the case of the Chief Executive Viticultural Officer; and the said Board shall have power to establish such quarantine rules and regulations as are required for the protection of fruit and fruit trees from the spread of insect pests.

SkC. 9. There is hereby appropriated for the uses of the Board of State Viticultural Commissioners, as set forth in this Act, and in the Act providing for its organization, out of any moneys in the State treasury not otherwise appropriated, the sum of ten thousand dollars for the year commenciug July first, eighteen hundred and eighty-one, and ten thousand dollars for the year commencing July first, eighteen hundred and eighty-two; and the State Controller will draw his warrants upon the State Treasurer in favor of the Treasurer of the said Board for the said sums, or any part thereof, when they become available, upon proper demand being made for the same by said Board; provided, that no claim shall be paid out of said appropriation until the same shall have been presented to and approved by the State Board of Examiners.

SEc. 10. This Act shall take eflect and be in force from and after its passage.

\section{A N A C I}

To Protect and Promote tife Horticultural Interests of the State.

The Peopie of the State of California, represented in Senate and Assembly, do enact as follows:

SECTION 1. Whenever a petition is presented to the Board of Supervisors of any county, and signed by five or more persons who are resident freeholders and possessors of an orchard, or both, stating that certain or all orchards, or nurseries, or trees of any variety, are infested with scale bug, codlin moth, or other insects that are destructive to trees, and praying that a commission be appointed by them, whose duty it shall be to supervise their destruction, as hereinafter provided, the Board of Supervisor's shall, within twenty days thereafter, select three Commissioners for the county, to be known as a County Board of Horticultural Commissioners. The Board of Supervisors may fill any vacancy that may occur in said Commission by death, resignation, or otherwise, and appoint one Commissioner each year, one month or thereabouts previous to the expiration of the term of office of any member of said Commission. The said Commissioners shall serve for a period of three years from the date of their appointment, except the Commissioners first appointed, one of whom shall serve for one year, one of whom shall serve for two years, and one of whom shall serve for three years, from the date of appointment. The Commissioners first appointed shall themselves decide, by lot, or otherwise, who shall serve for one year, who two years, and who three years, and shall notify the Board of Supervisors of the result of their choice. 
SkC. 2. It shall be the duty of the County Board of Horticultural Commissioners in each county, whenever they shall be informed by complaint of any person residing in such county, that an orchard, or nursery, or trees, or any fruit packing house, storeroom, saleroom, or any other place in their jurisdietion, is infested with seale bug, codlin moth, red spider, or other noxious insects liable to spread contagion dangerous to the trees or fruit of complainant, or their eggs or larvæe, injurious to fruit or fruit trees, they shall cause an inspection to be made of the said premises, and if found infected they shall notify the owner or owners, or the person or persons in charge or possession of the said trees, or places, as aforesaid, that the same are infested with said insects, or any of them, or their eggs or larva, and shall require such person or persons to disinfect the same within a certain time to be specified. 'If, within such specified time, such disinfection has not been accomplished, the said person or persons shall be required to make application of such treatment for the purpose of destroying them as said Commissioners shall prescribe. Said notices may be served upon the person or persons owning or having charge or possession of such infested trees, or places, or articles as aforesaid, by any Commissioner, or by any person deputed by the said Commissioners for that purpose, or they may be served in the same manner as a summons in a civil action. If the owner or owners, or the person or persons in charge or possession of any orchard, or nursery, or trees, or places, or articles, infested with said insects, or any of them, or their larvæe or eggs, after having been notified as above to make application of treatment as directed, shall fail, neglect, or refuse so to do, he or they shall be deemed g'ilty of maintaining a public nuisance, and any such orchards, nurseries, trees, or places, or arlicles thus infested, shall be adjurged and the same is hereby declared a public nuisance, and may be proceeded against as such. If found guilty, the Court shall direct the aforesaid County Board of Horticultural Commissioners to abate the nuisance. The expenses thus incurred shall be a lien upon the real property of the defendant.

SEC. 3. Said County Board of Horticultural Commissioners shall have power to divide the county into districts, and to appoint a local Inspector for each of said districts. The duties of such local Inspectors shall be preseribed by said County Board.

SEC. 4. It shall be the duty of said County Board of Commissioners to keep a record of their official doings, and to make a report to the Board of State Viticultural Commissioners on or before the first day of November of each year, who shall incorporate the same in their annual reports.

SEC. 5. It shall be the duty of the Commissioners at large, appointed by the Board of State Viticultural Commissioners for such purpose, to recommend, consult, and act with the County Board of Commissioners in their respective counties, as to the most efficacious treatment to be adopted for the extermination of the aforesaid insects, or larvæ, or eggs thereof, and to attend to such other duties as may be necessary to accomplish or carry out the full intent and meaning of this Act.

SEC. 6. Each County Commissioner and local Inspector may be paid five dollars for each day actually engaged in the performance of his duties under this Act, payable out of the county treasury of his county ; provided, that no more shall be paid for such services than shall be determined by resolution of the Board of Supervisors of the county for services actually and necessarily rendered.

SEC. 7. Each of said Commissioners may select one or more persons, without pay, to assist him in the discharge of his duties, as he may deem necessary.

SEC. 8. If any County Board of Commissioners, after having received complaint in writing, as provided for in section two of this Act, shall fail to perform the duties of their office, as required by this Aet, they may be removed from office by the Board of Supervisors, and the vacancy thus formed shall be filled in the same manner as provided for in this Act.

SFC. 9. Notbing in this Act shall be construed so as to affect vineyards or their prolucts.

SF. 10. This Act shall take effect immediately. 


\section{RULES RECOMMENDED}

\section{For the Protection of Fruit and Fruit Trees from the Ravages of Insects.}

RULE 1. It shall be required of every fruit grower, owner of an orchard or orchards, or lands containing fruit trees, or persons in possession of lands on which there are any fruit tree or trees which are infested with codlin moth, its larvæ or pupæ (ehrysalids), to destroy said codlin moth, its larvæ, or pupæ, before the first day of March each year, by scraping off all rough bark on said trees, and cleaning all erevices in bark and crotehes. The scrapings must be gathered carefully and destroyed by burning or otherwise. (A spread made of old grain sacks, or other cloth material, should be spread on the ground around the body of the tree before scraping.) After scraping, the tree should be washed with an alkaline wash made from a soft soap containing at least nine per cent. of potash. This soap, when made, mixed with twenty-five per cent. of its weight with flour of sulphur. One pound of this mixture to each gallon of water used for washing trees. Instead of this wash, the whale oil soap and sulphur mixture known as codlin moth wash, one pound to each gallon of water; or, a mixture containing not less than one pound of commercial concentrated lye to three gallons of water.*

RULE 2. All vegetable and other growth must be cleaned off the ground around trees infested with codlin moth, its larvæ or pupæ, before the fifteenth $\dagger$ day of May of each year, and the soil made as smooth as possible, provided that all premises under water at that time may be excepted as to date.

RULE 3. All boxes or packages stored in orchards or adjoining storerooms, sheds, or premises, from one season to another, especially those used for the shipment of apples, pears, and quinces, from orchards known to be infested with codlin moth, etc., or boxes and packages known to have been in contact with such, must be disinfected by dipping in boiling water for at least two minutes, such water to contain in solution not less than one pound of commercial potash or five eighths of a pound of commercial concentrated lye to each twenty-five gallons of water used for such disinfection.

RULE 4. All salerooms, storerooms, and packing-houses where fruit or fruit boxes or packages used in shipping pears, apples, or quinces, or any other kind of fruit infested with codlin moth, its larvæ or pupæ, or scale bugs (insects), or any noxious insects known to be injurious to fruit or fruit trees, have been used or stored for any purpose, must be thoroughly disinfected as preseribed by the Chief Executive Horticultural Officer, or local Inspector, or County Horticultural Commissioner of district in which the premises are located.

RuLE 5. All fruit infested with codlin moth, seale bugs (insects), or any noxious insects known to be injurious to fruit and fruit trees, must be picked off the trees and destroyed by cooking or feeding to hogs, or in any other manner satisfactory to the County Horticultural Commissioner or local Inspector of the district where such tree or trees bearing such fruit are located.

RULE 6. Before the fifteenth $\dagger$ day of May in each year, one or more bands of cloth or paper must be placed around each apple, pear, or quince tree contained or growing in any orchard where such trees or their fruit are known to be infested with codlin moth, its larvæ or pupæ. (Burlap, cut or torn in slips about eight inches wide, preferred.) The band or bands to be fastened around the body of the tree by cord or wire, or in any manner satisfactory to the Horticultural Commissioner or local Inspector of the district where such tree or trees are located.

RULE 7. The bands must be examined every seventh day, and the larvæ or pupæ found therein destroyed.

RULE 8. All fruit trees, plants, or scions (excepting grapevines and cuttings), infested by scale bugs (insects), must be thoroughly disinfected by dipping or otherwise washing in an alkaline mixture containing not less than one pound of commercial concentrated lye to every two gallons of water, or by such wash as may be satisfactory to the Horticultural Commissioner or local Inspector of the district where such trees are located or in store.

RULE 9. Any fruit tree or trees, plants, or scions, in any orchard or in any place, infested by red spider (mite), must be thoroughly washed with an alkaline wash as prescribed in Rule 8 , or by such wash as may be satisfactory to the Horticultural Commissioner or local Inspector of the district where such trees are located or in store.

* Where the washes containing sulphur have been used, they have proved an excellent preventive against mildew.

+ In districts where fruit ripens later than at Sacramento, the dates in Rules Nos. 2 and 6 may be made fifteen days later, viz: thirtieth day of May. 
TuLE 10. Empty boxes or packages returned from market, or any place whence shipped, with fruit infested with codlin moth, its larvæ or pupæ, or scale bugs (insects), or any noxious insects known to be injurious to fruit or fruit trees, or known to have been in contact with any boxes or packages containing fruit infested by said insects, must be disinfected by dipping in boiling water as prescribed in Rule 3.

RULF 11. In cases where notice is served to disinfect empty boxes or packages just returned from market or in transit, the time allowed from date of notice shall not be less than one day.

RUIF 12. In cases where notice is served to disinfect empty boxes or packages used the previous year, the time allowed from date of notice shall not be less than three days.

RuLE 13. In cases where notice is served to destroy fruit on trees infested with codlin moth, its larvæ or pupæ, or any noxious insect or insects known to be injurious to fruit or fruit trees, the time allowed from date of notice shall not be less than six days.

RuLE 14. In cases where notice is served to place bands on trees as prescribed in Rule 6, the time allowed from date of notice shall not be less than ten days.

RUs. 15. Any tree or trees, plants, or shrubs (grapevines excepted), infested by any species of scale bug (insect), red spider (mite), or any noxious iasect or insects liable to spread contagion to fruit or fruit trees, must be disinfected with an alkaline wash as prescribed in Rule 8, or such wash as may be satisfactory to the Chief Horticultural Officer, or local Inspector, or County Horticultural Commissioner of the district where such trees are located.

\section{DAMAGE TO ORCHARD PROPERTY AND FRUIT CROPS.}

The aggregate amount of damage to orchard property in California by depreciation in value, caused by spread of insects injurious to fruit and fruit trees, within the last five years cannot be accurately stated, as there are not any statistics to refer to, but it can be safely estimated at two million of dollars. It is not claimed that this amount of actual damage was done, but fruit growers were ignorant of any reliable remedy, causing a greater depreciation in value than was necessary. The damage to apple, pear, and quince crops, by codlin moth and scale insects, since 1877, is at least fifty per cent. of whole crops produced. If to the above is added the damage to plum and orange crops, by scale insects; by red spider (mite), on almond and cherry crops; the loss in currant orchards by borers; and the damage by caterpillars, squash bugs, etc., to fruit and foliage, not more than thirty-three and one third per cent of what the orchards are capable of producing can be classed as choice marketable fruit.

Inquiries concerning diseases of trees and insect pests, not found heretofore in orchards, are frequent; all tending to prove that the prospects of fruit growers in this State, are not encouraging, if active measures are not adopted for the extermination of insect pests.

Query.-Can our orchards be protected from the ravages of insect pests?

Answer.-Yes, undoubtedly ; by a united warfare for the destruction of insect pests by all persons owning fruit trees, and other varieties of trees infested by noxious insects. 


\section{THE CODLIN MOTH.}

"The Codlin Moth is now one of the permanent institutions of the State, and fruit growing, or at least apple and pear growing, have been rendered very unsatisfactory and uncertain." Sacramento Record-Union.

It is not necessary for our purpose to detail the amount of damage done the apple, pear, and quince crop of central California since 1874, by the insect pest known as the Codlin or Apple Moth (the parent of the apple worm), as unfortunately it is too well known.

The moth belongs to the family of Tortrices, and is known to naturalists as Carpocapsa pomonella (the Codlin or Apple Moth). The moth passes the Winter in the larva state, and in some instances, in the chrysalis form. The larva can be found under the loose bark, in the crotches, or indents, or cracks in the bark of trees infested t. ce pre-

FIG. 1.

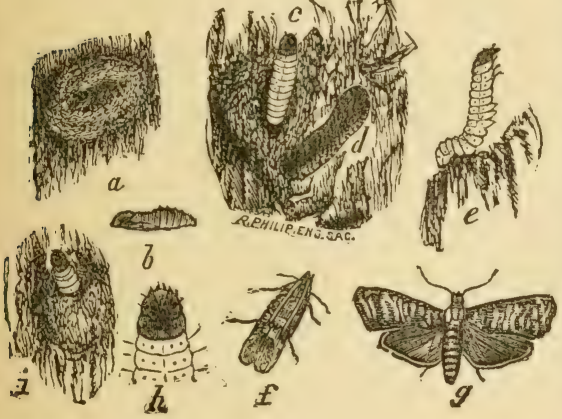
vious year, or in the crevices of wood or wood work of rooms, or places where fruit infested by the larva was stored or packed. It is often found hibernating on bark of trees, from one to six inches below the surface of the ground. especially if the trees have smooth bark. In one case, where four hundred apple trees were dug up last Winter, the larvæ were found in large numbers in the roots of such trees as were decayed at, or above the surface of the ground.

Description of Fig. 1.

a.-Nest of larva as it appears on inside of bark when taken off tree. Color, drab.

b.-Pupa or chrysalis. Color, dark amber.

c.-Appearance of larva when cover is removed off Winter nest. Color, body yellowish white, head dark brown.

d.-Appearance of bottom of Winter nest on bark when larva is removed following Spring.

e.-A position the larva takes when looking for a tree or place to make its nest, when ready to assume the pupa or chrysalis form.

NoтE.-When the larva are full grown and ready to assume the pupa or chrysalis form, color light pink.

f.-The moth-first appearance as perfect insect, carries its wings like a steep roof.

g.-Moth with wings spread. Length of body, seven-sixteenths of an inch; spread of wings, nearly three-fourths of an inch; color, body and legs, rich bronzed light drab; fore wings, mottled gray and drab, with dark copper bar across hinder margin, on which is a golden occellated patch near inner angle; hind wings, plain drab, a little darker than body. The moth, after depositing eggs, has assumed a light drab color on fore wings, and copper bar a very light color, scarcely perceptible, caused, probably, from flying among the branches and leaves.

$h .-$ Head of larva as seen through a glass magnifying power nine times.

$i$.- In this figure we intended to represent the pupa or chrysalis case growing through nest prior to moth leaving it, but represented as larva, to show better.

NoTE. - The figure would be correct if the chrysalis (b) was represented instead of larva (c).

The figures $a, b, c, d, e$, and $f$ are natural size; $g$ is a little larger than natural size; $h$, as described. 
If the Spring is warm and farorable, the larvæ are ready to assume the pupa or chrysalis form by the fifteenth of April. The duration of the lupa or chrysalis state depends on external circumstances. If warm, Spring weather, the perfect insect may appear in from fifteen to twenty days, and may be prolonged to twenty or thirty days.

The Spring of 1881 has proved an exception. We were shown Madalene pears on the sixteenth of May in which the larva had matured and left; also, on May 7 th, found a pear with larva about eight days old. ('This is about eighteen days earlier than usual.)

\section{FIRST APPEARANCE OF THE MOTH.}

The moth generally appears from April 25th to the 15th of May; a few in favorable locations by April 15th. The time at which the eggs arrive at maturity apparently coincides with the end or termination of the pupa or chrysalis state, so that the sexes are ready to unite soon after transformation.

The moths produced by the hibernating larve deposit their eggs in the blossom end (or calyx) of the fruit, generally; possibly

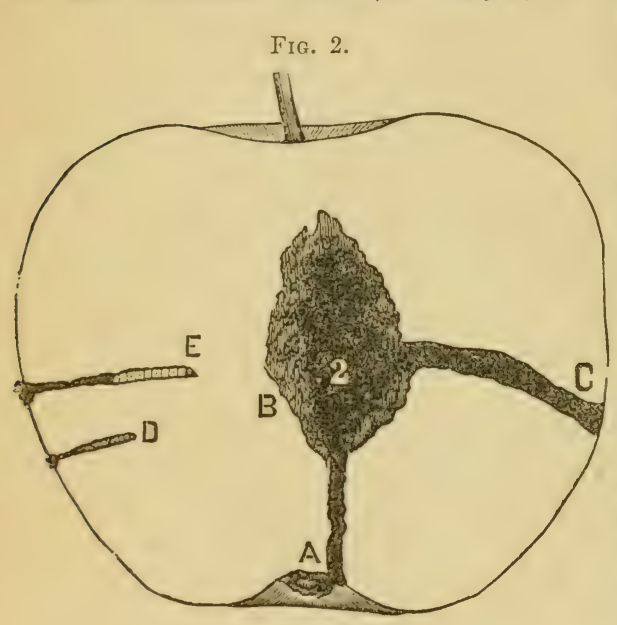
because they cannot puncture the epidermis (or skin) of the young fruit. Later broods deposit their eggs on any part of the fruit. The eggs are attached to the fruit by a pasty substance. At the time the egg is deposited the skin of the fruit is punctured, making easy entrance for the young larva. It is rare to find more than one egg on any apple, pear, or quince, or more than one larva. The larva is hatched in from seven to ten days, and begins to eat eagerly and burrow towards the carpellary ovarium, or core containing the seeds. (B, Fig. 2.)

Description of Fig. 2.

A.-Blossom end or calyx of apple, and where larva is supposed to enter the fruit.

B.-Represents an empty space where carpellary ovarium or shell containing the seeds were located before the entrance of larva.

C.- Represents the burrows made by the larva through the pericarp, by which it escapes from the fruit when it is ready to assume the pupa or chrysalis form.

D.-Appearance of larva in burrow when six days old.

E.-Appearance of larva in burrow when ten days old.

The larva, when hatched, can scarcely be seen with the mnaided eye; at six dars, measures nearly one quarter of an inch in length, about as thick as fine silk thread. First signs of excrement at burrow (D, Fig. 2); at ten days, three eighth of an inch, and about as thick as a number twenty wire (E, Fig. 2). It has burrowed by this time about three fourths of the distance to the sced bag of fruit 
(B, Fig. 2); at twenty days, nearly full natural size (c, Fig. 1), and often as large as $e$, Fig. 1 .

When the larva is ready to assume the pupa or chrysalis form, it leaves the fruit by gnawing a hole through the pericarp (C, Fig. 2). Nature has supplied it with a spinneret, the opening apparently in the lower lip, from which issues a viscid fluid in a fine stream, and hardens into silk on contact with the air. By this means it lowers itself to the ground or intervening branches. If it reaches the ground, it immediately crawls toward the tree; and on its journey can often be seen as $c$, Fig. 1 . On reaching the tree, it searches for a nesting place under the loose bark in the crotches, or any cavity it can find. If it comes in contact with a branch when leaving fruit, it generally crawls toward the crotehes, or until it reaches a hiding place. If under the loose bark, it commences building an oval-shaped wall, about one sixteenth of an inch high, composed of silk from the spinneret, and sometimes mixed with pieces gnawed off the bark. A silken cover is then put on the nest by using the spinneret; the whole completed in twenty-four hours (a, Fig. 1). If in a crevice of the bark, the nest is made in different shapes. It is noticeable in the Winter nest tinat the tops and sides are washed with fluid from spinneret, making the nest water-proof to a great extent.

The moth remains in the pupa or chrysalis form from nine to twelve days, in our usual May weather. At the proper time the pupa case is burst open, and the perfect moth appears ( $f$, Fig. 1).

It may be asked, how does the moth get out of the nest so neatly made, etc.? About twenty-four hours before transformation, the pupa forces its way through one end of the nest ( $i$, Fig. 1-see note in description), so that the perfect insect can easily escape.

The chrysalids of this moth are capable of moving, from the time they assume the chrysalis or pupa form, until the insect escapes perfect.

\section{PROBABLE RATE OF INCREASE OF THESE MOTHS.}

Entomologists claim that of the lepidopterous insects, including butterflies and moths, nearly one thousand kinds are known in the United States. That each female lays from two hundred to five hundred eggs.* Taking two hundred as the lowest number, twelve female moths in one orchard would produce two thousand four hundred caterpillars; if one half these were females, they would produce two hundred and forty thousand. In proportion, the third generation would reach twenty-four millions, supposing that no untimely deaths took place.

Most of the books on this subject speak of the codlin moth as going through but one generation in a year. This may be true in colder climates and shorter seasons than ours, but in parts of our favored State there is no question that two or three generations or broods are common. From personal observation, we know that the rule for the Sacramento Valley is three broods each year. This year (1881), on account of the early apjearance of the first moths, as noted above, we shall probably have four broods. These facts explain the exceptional importance of this insect in California.

*We have in our possession a vial containing eighty-five eggs deposited by one moth, Carpocapsa pomonella. 
Is this pest of the orchard only found in California? The damage done by this pest in the States east of the Rocky Mountains is too well known to need repeating.

It has also infested many orchards in Utah Territory, and has seriously damaged the apple and pear crops in Tasmania, Australia.

\section{REMEDIES RECOMMENDED.}

From the observations stated, we are led to believe that the destruction of this pest must be consummated while it is in the caterpillar state.

At any time between the first day of November and the first day of March of each season, all the apple, pear, and quince trees, in any orchard infested by codlin moth, should be carefully scraped, and ail loose bark removed, as follows:

FIG. 3.

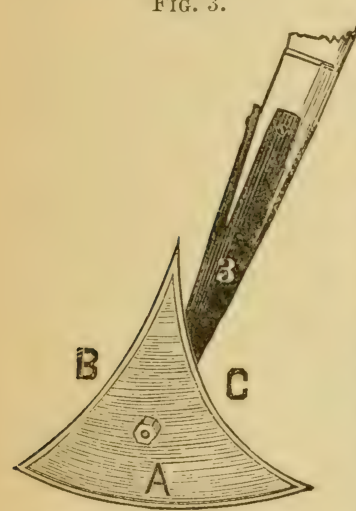

Provide some small ship scrapers and grind two of the edges to a concave curve (Fig. 3) so that they will fit the trunk of the tree better than a straight edge can (B and C, Fig. 3). Scrapers having a length of side of four inches, will be large enough, use handles to suit. Procure a cloth made of old sacks or any material convenient, spread on the ground around the tree as far as the scrapings are likely to fall; then commence on the tree as far up as there is any rough loose bark, and scrape it carefully off. Also examine and scrape all crevices in the bark or those formed in the crotches of the tree. Continue scraping until you reach the ground. This done, gather the scrapings carefully off the cloth, so that they can be burned or otherwise destroyed immediately.

Be careful that you do not neglect gathering carefully the scrapings and destroying them, as on this point depends a great deal of your success.

By thus burning the debris taken from the trees, the larvæ hibernating in the debris are destroyed.

In order to destroy any larvæ remaining on the tree, or in the crotches, indents, or cracks, also to inaugurate the growth of a new smooth bark, a wash should be applied as recommended in Rule 1, page 11. The wash should be applied at a temperature of one hundred and thirty degrees.

Take a common whitewash brush and give the tree a good coat of the solution, or use a garden force pump of some form, commencing at the top as far up as there are any cracks or crevices in the bark, and wash down to the ground. Repeat the washing before the Spring; this will destroy any larvæ or chrysalids left on the tree.

Bands should be placed on trees as follows: Take a piece of common straw wrapping paper, say twenty-four inches long and ten or twelve inches wide, double it lengthwise (this will be sufficiently long for a tree seven inches in diameter-larger trees will require longer bands, in one or more pieces), and put around the tree a few inches above the ground; fasten it with a piece of wire or narrow 
strip of tin-either of them is preferable to cord, as they can be pressed into the dents on the surface of the tree.

From experiments made, bands made of burlap or old grain sacks torn in strips are preferable. (See Rule 6, page 11.)

The larva creeping up the tree, makes its nest under the band. These bands should be examined every seventh day, the larræ collected and destroyed. Paper or rags laid on the ground around the tree will answer partly the same purpose, but may not be so easily examined. It is also recommended that some paper or rags should be placed in the crotches of the tree and on the rough branches, so as to entrap any larva coming down the branches looking for a nesting place, and these should be examined as regularly as the bands.

The use of bands only is advocated by many Eastern fruit growers, and also by some persons on this coast. A fruit grower of Nonroe County, New York, reports experiments made by him, as follows:

"He placed one band near the ground, on each of three trees, and captured, during the season, on the three trees with single bands, one hundred and ninety-eight larvæ, or sixty-six for each tree. On three trees he placed one band near the ground and one band near the crotches. On the three trees with double bands, during the season, he captured three hundred and eleven larvæ, or nearly one hundred and four for each tree."

The experiments referred to are proof that the band system worked admirably. But your attention is called to the fact that five hundred and nine apples or pears were destroyed previous to the larvæ being captured in the bands, with chances in favor of some escaping, which, if compared with the estimated rate of increase, would only be equal to the capture of a small number of the early moths. By scraping and washing the tree, as heretofore described, the larvæ or pupæ hibernating are destroyed, and prevented from propagating their kind.

A prominent fruit grower, whose orchard is near to this city, purchased three hundred hogs, and placed them in his orchard. He employed men to pick fruit off his trees showing signs of larvæ. The hogs followed the men from tree to tree, and ate all fruit thrown down. This operation was often repeated, so that the early broods were nearly destroyed, and a large percentage of the late crops saved. This is an excellent remedy, but expensive. Fruit infested picked off the trees and destroyed, will prove successful to the extent practiced.

IMPORTANT POINTS.

To be successful, use every effort to destroy the spring brood of moths.

Any means taken to destroy the early broods will prevent the late fruit from being lost.

The Natoma Fruit Company, Folsom, Sacramento County, scraped, washed twice, and banded twenty-five hundred pear trees, at an average cost, labor included, of six cents per tree. 
Disinfect all boxes returned from market before taking into the orchard. (See Rule 10, page 12.)

We have read statements by fruit growers that they have seen the codlin moth flying in large numbers. In our investigations we have not seen more than two at any one time.

The moth will live in glass seven days.

The female moths deposit their brood of eggs within forty-eight hours.

The egg cannot be seen plainly by the unaided eye.

The best time to see the moths at work is at dawn of day, in the months of June and July.

We do not think the female moths can be decoyed from the trees by burning lights at night in orchard, until all the eggs in the ovary are deposited.

The moth deposits the eggs at night.

Only united action of fruit growers will gain a complete victory over this pest.

Defer not your action-the time arrives as soon as the leaves fall.

Part of the early fruit falls prematurely, when attacked by larvæ, but little of the late fruit falls before the larvæ escapes.

The theory that the moth always deposits the egg on the fruit blossom, and that it remains there until the fruit has grown to natural size, is a mistake.

It is necessary where an examination is made of an orchard, to examine every tree carefully, of the apple, pear, and quince varieties.

There are three broods of the codlin moth at least, each season, in the great central valley of California.

Supposing the moth matured from the Winter larvæ on the first day of May, the first brood of the season would reach perfection by the twentieth of June, and the second brood by the twelfth of August. Those matured after the twentieth of August deposit the egg that produces the larvæ and chrysalids for the next season.

'The larva apparently prefer' the quince, and soft-barked apple trees for passing the Winter (hibernating).

Do not think that the moth that produces the larv found on dried fruit and the codlin moth are the same. This is a different species. Description: Length, half an inch; spread of wings, three fourths of an inch; color, body dark drab; fore wings, yellow bar one eighth of an inch wide across shoulders, balance of fore wings mottled dark brown; carries wings roof-shaped; hind wings dark drab.

It is not generally known how to distinguish the sexes of the codlin moth. Mr. Zeller discovered, on the upper surface of the hind wings of the male, a black pencil, or tufts of hair of considerable length. It grows from a point close to the base of the wing, and lies in a groove rumning alongside of the median nervure, about half the width of the wing, the groove forming a distinct keel-like mark on the under surface. It is not casily noticed, but can be readily detected on close examination. It can be raised by the point of a needle.

\section{HOW TO EXAMINE THE TREES TO FIND LARVA.}

Open the large blade of a pocket knife, and with its point and fore finger take off carefully the pieces of loose bark; examine the inside 
part, and if the larva is there, you will find the nest, as shown in a, Fig. 1. On removing the cover of the nest, it may contain either the larva (b, Fig. 1) or chrysalis (c, Fig. 1). All crevices and dents in the bark, and crotches, should be examined carefully. Some persons throw the bark away before examining it, thinking the nest is always on the tree; this is a mistake.

\section{HOW TO PROCURE SPECIMENS OF THE MOTH.}

When you find the larva, if it is not on the loose bark, remove the piece of bark to which it is attached, place it in a small vial, and, if in the Summer time, inside of twelve days you will have a genuine specimen of the moth ( $f$ and $g$, Fig. 1). Fruit growers can get important information concerning the natural history and habits of the insect pests by experiments of this kind.

Every fruit grower should unite in the crusade against this pest. "In union there is strength."

\section{PEAR SLUG-Selandria cerasi. (Peck.)}

Fig. 4.

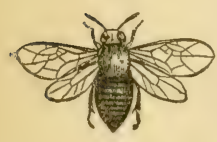

Fic. 5.

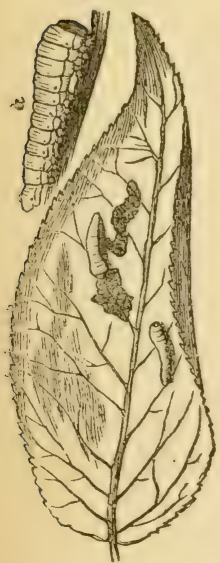

"The pear slug (Fig. 4), and larvæ feeding on a leaf of a pear tree, and showing the surface eaten in patches, is a twenty-footed larva. It narrows rapidly behind the swollen thorax, and is covered with a sticky, olive colored slime."-Packard.

This pest has been reported this season from several counties, and appears to be spreading rapidly. It feeds upon the leaf of the pear,but is known to attack other varieties of trees. It eats the epidermis (skin) off the leaves. (See Fig. 5.)

The egg is laid in a cut made in the leaf by the sawlike apparatus of the female, and the young larva is hatched in a few days, and begins eating the surface of the leaf. The larva, when it ceases feeding, drops to the ground, crawls beneath the surface, and spins a cocoon, and evidently hibernates in the ground. The fly is shining black; wings, hyaline (clear); lower parts of anterior legs a dirty white. There is apparently but two broods in each season.

The full grown larva measures forty-five one hundredths of an inch in length; pupa ovate, and the adult insect, twenty-eight one hundredths of an inch. Spread of wings, fifty-two one hundredths of an inch.

\section{Remedies.}

Sulphur, or powdered lime, or sulphur and lime (powdered) mixed, dusted on the leaves infested will effectually destroy the larvæ.

Dust taken from the highway and dusted on the leaves, is reported to have proved effective in destroying the larvæ.

Spray the foliage with either of the sulphur washes recommended in Rule 1, page 11, and it will prevent the larvæ from maturing. 


\section{SAW FLY-Nematis similaris. (Norton.)}

In the last few years considerable damage has been done to foliage of pear trees, in vicinity of Sacramento, by a small green larva. In the present season (1881) it has been reported from several counties.

Fig. 7.

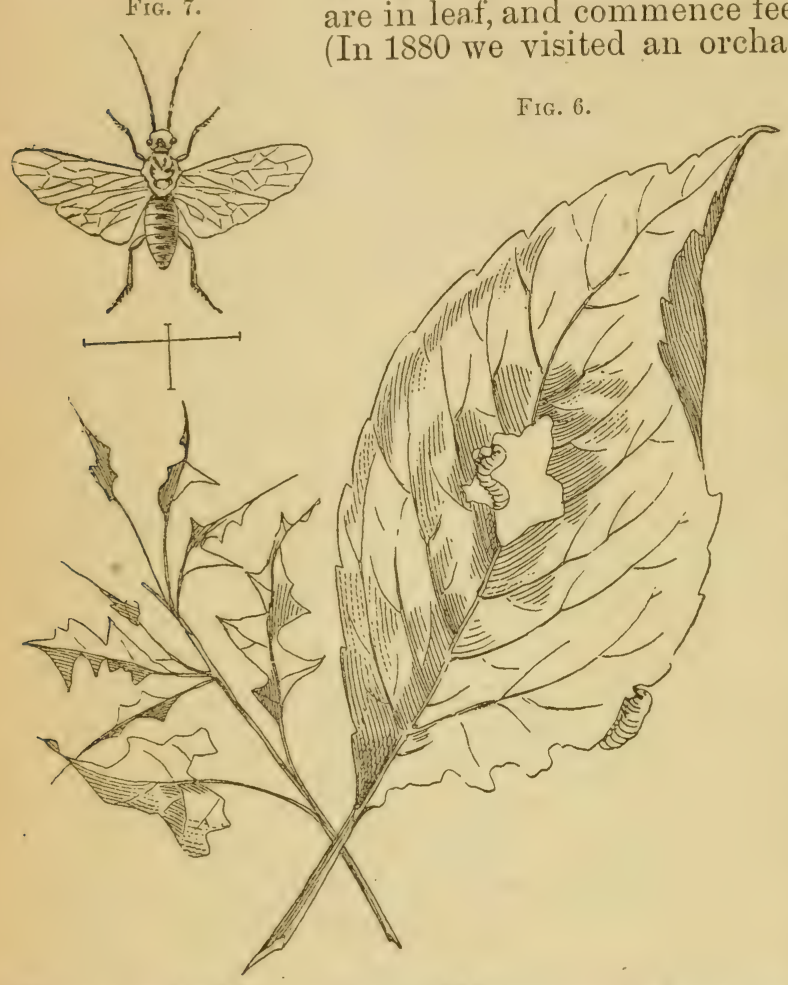

The young larvæ appear about the time the trees. are in leaf, and commence feeding on the foliage. pear trees of the Winter Nellis variety almost entirely stripped of foliage.)

The egg is laid by the female fly in a cut made in the leaf by the sawlike apparatus of the female, and hatches in a few days. At first it. eats a short track along the leaf, then a small hole, and fastens itself by pro-legs. (Fig. 6.) When about one third grown, it leaves this hole, and either commences eating on the edge of the leaf or on the edge of another leaf, which it generally destroys (devours)entirely continuing from one leaf to another. (Have counted six larva on one leaf.)

The larva, full grown, measures one half of an inch in length, has six thoracic legs, twelve pro-legs, and two anal pro-legs; is a green color; the head is yellowish-green, the eyes black. When it ceases feeding the larva drops to the ground, or into the crotches of the trees or branches, and hides itself. It spins a tough, dark-brown, oval cocoon. In this cocoon it hibernates as a larva. (TVe judge from specimens kept through Winter of 1850-81, and from specimens now in our jossession.) Only one brood has appeared each season.

The adult insect (Fig. 7) is about three tenths of an inch in length ; expanse of wings, about three fifths of an inch; the upper part of head and thorax, black; abdomen, yellowish with a black transverse band on dorsal half of each segment; wings, hyaline (clear), of a. brownish hue. 


\section{Remedies.}

When the trees are planted in sandy soil, build a cone of sand around base of tree, then shake the branches; the larvæ, falling to the ground, cannot reach the tree over the sand placed around base; or, place a greased cloth band (see Art. Caterpillar, page 23) on the tree, then shake the branches; the larvæ, falling off, cannot ascend the tree over the greased band. This should be done before the larvæ are full-grown. Or spray the foliage with either of the sulphur washes. (See Rule 1, page 11.)

\section{RED SPIDER - Tetranychus telarius. (Linn.)}

The red mite, commonly called red spider, may be said to be a universal pest of the garden and hothouse, and, within a few years,

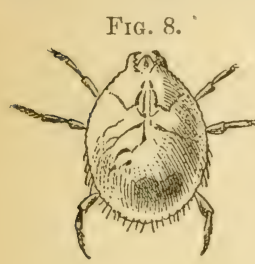

FIG. 9

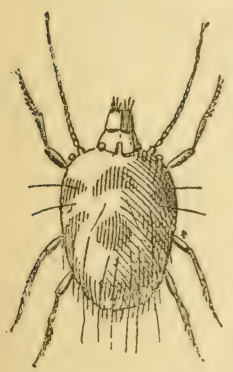

Fic. 10.

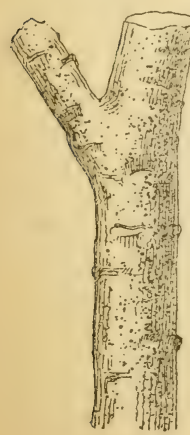
has spread (as it were, unnoticed), until many orchards in this State are seriously infested by it. This pest is especially noticeable on the almond trees, and is found on the apple, pear, plum, cherry, etc. Appearance of almond trees infested by red spider: The body, or trunk of the tree, limbs, and branches, are a red color, and foliage sparce; on others, the limbs and branches appear covered with iron-rust (Fig. 10); these signs denote the presence of myriads of these pests. On trees not seriously infested, they are generally found around the buds and branches. They are also found in trees infested by the scale insect. The red color mentioned is the color of the myriads of ova covering the surface of the bark, but can only be plainly seen with the aid of a glass. Observation leads us to think that the female does not deposit eggs, but, at maturity, fastens herself to the bark or leaf, and dies. The covering removed, from fifteen to twenty whitish ova are found. The ovum changes, by an outer shell falling off, leaving an ovum of a red color, which produces a six-footed mite; color, bright

red; legs scantily covered with spines. (In the females can be seen what may be termed germ balls, Fig. 8 , as in some of the cecidomyian larvæ.) In a few days it changes to an eight-footed mite (Fig. 9); color: body, blackish red; head, yellowish. The injury done by these mites is principally on the fruit and flower buds, and leaves, from which they take off the skin or epidermis, and by making a very fine web over the surface of the leaves and branches (the web is so fine it cannot be seen by the unaided eye). The matter noticed on the branches and foliage is, to a great extent, the debris left by the mites during the metamorphoses (changes). The debris and web prevent free respiration to the parts covered.

This pest is found in every fruit growing county in the State, on all kinds of citrus and deciduous trees. 


\section{Remedies.}

1. Leaves falling off trees infested by these mites should be carefully raked together and burned.

2. All prunings of trees infested should be burned.

3. By spraying (or washing) the parts of a tree infested, before it leafs out, with a solution: One pound of commercial concentrated lye to one and a half gallons of water. Repeat the spraying (orwashing) before the bloom appears, with either of the sulphur mixtures recommended in Rule 1, page 11.

Foliage and fruit of almond trees seriously infested with red mites. this season, were washed with whale oil soap and sulphur mixture about the first of June, and proved successful.

Dr. S. F. Chapin, of San José, exterminated the mites and ova on young deciduous trees by washing with a solution: One pound of concentrated lye to one gallon of water.

\section{CATERPILLARS.}

The orchard of Mr. DeLong, at Navato, Marin County, was infested' last Spring by caterpillars-a specie of the genus Clisiocampa, orTent Caterpillar. The caterpillar is one and three fourths inches in length, one fourth of an inch in diameter, and was full grown by the twelfth day of May. The body is sparingly clothed with soft and short hair, rather thicker and longer on the sides than elsewhere. The head is dark brown on each side, and dark brown above, leaving an inverted $\mathrm{Y}$ mark in the middle and front, jet black, and having much the appearance of a goblet, as one looks from its tail to head. The frontal mark is jet black, edged with a white strip. across and over the mouth parts, and on each side of the inverted Y. The ground color of the upper part of the body is evidently blue, with a dorsal row of oval orange spots, one on each segment; two subdorsal orange lines; also, two lateral orange lines. The dorsal space not covered by dorsal spots, between the subdorsal lines, is crinkled with fine black and orange lines; between the subdorsal and lateral lines, on each side, the space is blue, slightly variegated with fine orange and black lines intermingled. The lower part of the body and feet are dusky blue, crinkled with orange and black, irregular lines, and an amber colored ring around base of prop-legs. The caterpillars do not make a tent or web, although they live in

FIG. 11.

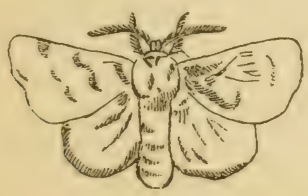

FIG. 12.

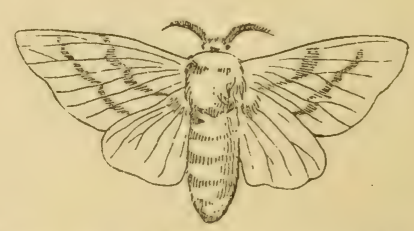

colonies on the tree. The caterpillars spin their cocoons (Fig. 13) in the folded leaves (Fig. 14) of the trees on which they feed, especially the apple. Pupa elongate, posteriorly attenuated, inclosed in a loose. 
silken web, suffused in fine yellow powder. The moth appears in about sixteen days; is reddish brown, with two transverse, rust-

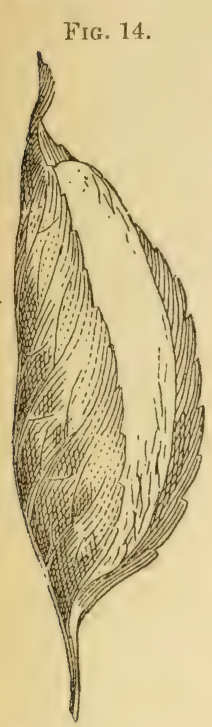
brown, nearly straight parallel lines, on the fore wings. Male (Fig. 11.) Antennæ, short curved, moderately bipectinated in both sexes, the pectinations gradually decreasing in length to the apex, and shortest in females; thorax, robust, pilose (hairy); abdomen, elongate, robust in female, and tufted in both; femura (thigh) and tibia (shin) hairy. It expands one and three fourths inches.

FIG. 13.

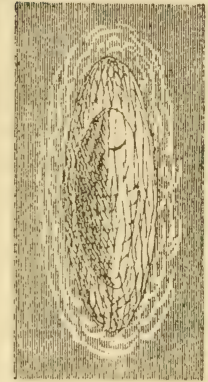

FIG. 15.

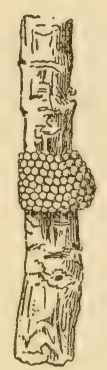

FIG. 16.

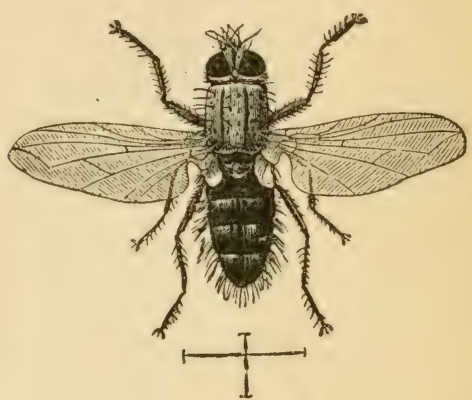

The female moth (Fig. 12) lays her eggs, about two hundred in number, in rows around the new growth of wood (Fig. 15), and covers them with an apparent water-proof substance, to protect them through the Winter season. About the time the leaves are unfolding in the Spring, the young hatch, and feed on the foliage and young fruit. Mr. De Long had a block of two thousand apple trees completely stripped of fruit and foliage.

\section{Method adopted by Mr. DeLong for destroying the Caterpillars.}

He placed a band of butter-cloth about four inches wide, covered with tallow, on the trees about two feet above the ground. He discovered that the caterpillars could form bridges over the tallow, especially at night. Over the tallow he placed soft lard, which proved effective. He then swept the caterpillars off the branches on to the ground. The caterpillars attempted to ascend the tree again, but would not cross the greased band. While thus gathered between the bands and the ground they were destroyed in immense numbers. To clean twenty-two thousand trees in this way it cost seven and one half cents per tree, and the work done in less than four weeks. Although the orchard is not thoroughly cleaned, Mr. DeLong saved the greater portion of his crop of twenty thousand trees for this season. These caterpillars can be effectively exterminated by carefully examining the young wood before the tree is leafed out, and picking off and destroying the bunches of eggs, also by picking off and destroying any cocoons found on the trees-there is often found a leaf folded containing six or seven cocoons. However, Mr. DeLong is confident he can exterminate them next season, by placing the greased bands on the trees and shaking the young cat- 
erpillars off the branches, etc., thus preventing them from maturing. The moth is the Clisiocampa constricta, Strech. 'There is another' species of the Clisiocampa that is spreading at and around Santa Cruz, and also in parts of Santa Clara and other counties, and is probably the Clisiocampa americana. The moth differs but little in appearance from the Clisiocampa constricta - the lines on the forewings are

Fig. 17 .

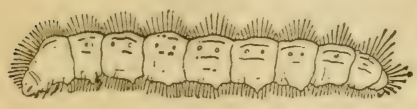

oblique and are a dirty white color, and the apex of the forewings are Fig. 18. shorter (Fig. 19). The caterpillar (Fig. 17) head, black; frontal mark inverted $\mathrm{Y}$, same as Clisiocampa constricta; ground color of back and sides, apparently brownish black; two dorsal lines, orange, space between crinkled black and orange lines, excepting first and second segment of thorax, dorsal half orange. 'Two lateral lines, orange, one on each side of stomata, with crinkled yellow lines forming a row of large black spots, one on each segment; lower part black, pro-legs reddish brown, and stylets and thorax legs black; whole body clothed with soft reddish brown hair. On full grown specimens, lateral tuft on thorax rings, whitish. The female lays her eggs on the side of a twig

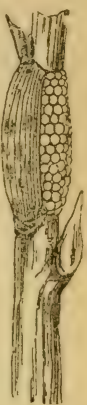
(Fig. 18), not entirely surrounding as Clisiocampa constricta, but covers them for protection in the same manner. This species makes a tent. This species can be exterminated by picking off and destroying the bunches of eggs before the tree leafs out, and by picking off and destroying tents, when made; or the latter may be burned with their occupants at such hours of the day as the caterpillars are at rest. A torch made of rags, bound upon a pole and saturated with kerosene is a useful weapon for this kind of warfare.

In Santa Cruz County, the caterpillar of the Orgyia leucostigma, or the white marked Orgyia or 'Tussock moth, is effecting considerable

FIG. 19 .

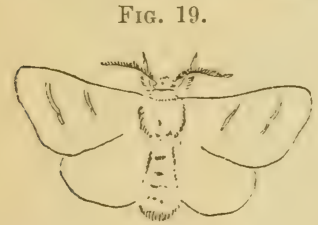

FIfi, 20.

FIG. 21.
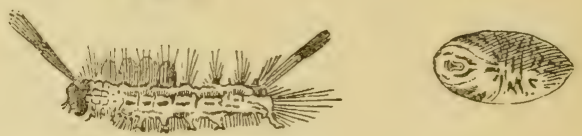

damage in apple orchards infested by it. The pretty caterpillar (Fig. 2() is one and a half inches long, in color light drab, and covered with fine silken hair. On each segment ring on the dorsal half are four red tubercles; from the outer tubercles on the first thorax ring grow tufts of black hair, forming two pencils projecting over the head; and from a tubercle on the eighth abdominal ring also grows a tuft of black hair, forming a pencil projecting over the anal appendages. From the inner tubercles on the second and third thorax rings, and first and second abdominal rings, grow thick tufts of drab colored hair, and join together presenting on these four rings a pretty brushlike growth. The head has an inverted Y mark, similar to Clisiocampa constivicta. The cocoon is made in the crevices of bark, etc., on the body and branches of the tree. Pupa of male, elongate, posteriorly attenuated, inclosed in a coarse silky cocoon. Pupa of female 
(Fig: 21), ovate in shape. The male moth (Fig. 22) has broad wings, pectinated antennæ. Female (Fig. 23): wingless, eggs generally de-

FIG. 22.

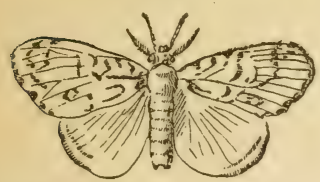

Fig. 23.

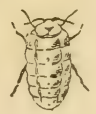

Fig. 24.

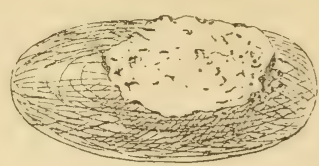

ces of the tree infested the previous season.

posited on outside of cocoon. (Fig. 24.) This species can be exterminated by gathering the bunches of eggs found in the crevi-

\section{Parasites on Caterpillar's.}

Specimens of caterpillar, Clisiocampa constricta, taken from Mr. De Long's orchard, about thirty-three per cent. were infested by parasites, principally a Tachina fly (Fig. 16), and some small Ichneumon flies. Specimens of both were bred from pupæ. From pupæ of orgyia, a specimen of an Ichneumon fly was bred; if not the Cryptus nuncus, closely allied thereto.

\section{CURRANT BORERS.}

The following description of the Egeria tipuliforme was written by Mr. C. H. Dwinelle of the University of California, 1880, which we take the liberty of copying:

"The currant bushes about Berkeley have for some years suffered very much from the attacks of an insect which eats out the pith of the main stem and branches. For the purpose of securing the winged form of the insect, branches containing chrysalids were a few weeks ago taken from the University garden, broken into pieces a few inches long and placed in a wide-mouthed bottle, with wire gauze over the top. On the twenty-fifth of May several of the insects were found to have completed their changes, and to have emerged as moths. They were soon identified as of a species but too well known in Europe, and imported thence into America, the currant borer (Ageria tipuliformc.) This pest is worthy of study on its own account, and as a member of a notorious family, with which the horticulturists of California may come to have an unpleasant acquaintance. This family of moths is peculiar, both in appearance and habits. The Egerians: belong to the clear-winged type of moths, having in general wings which are almost as transparent as those of a wasp. As they fly during the heat of the day, a casual observer might easily mistake them for wasps or closely related insects.

"The life history of the insect is as follows: The female of the currant borer lays her eggs singly on the wood of a year old or over, and usually by the side of a bud or branch. When hatched, the young larva makes its way into the center of the stem, and taking a downward course, eats out the pith for a distance of several inches. The borer is of a general white color, with a brown head. There are a 
few short hairs scattered over the body. Besides six true legs in front, there are ten fleshy prop-legs farther back. When full grown the borer is nearly half an inch in length and slender in proportion. In the Spring, the borers, for the most part, assume the form of a shining brown chrysalis, but, as with other borers of this group, there is a good deal of irregularity as to the time of making this change. At times the insect can be found in all three forms-larva, chrysalis, and moth. As the time for the moth to emerge approaches, the chrysalis assumes a dark blue tint. It also works its way to the opening of the burrow by a squirming motion, aided by rows of sharp pointed projections on the abdominal rings. When the moth escapes, it frequently leares the brown shell of the chrysalis sticking in the mouth of the burrow."

Fig. 2.5.

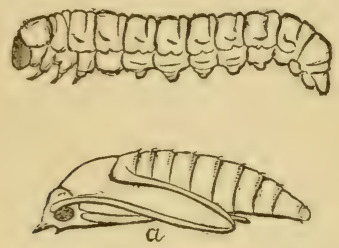

FIG. 26.

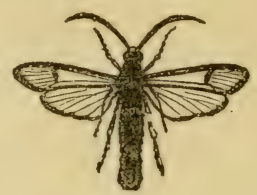

Inth, Grub, and Chrysalis of Currant Borer.

The illustration of the currant borer, Egeria tipriliforme, which is given on this page, is copied from Packard. The larva and chrysalis are very much enlarged. The natural size of the grub, as stated above, is not more than half an inch when full grown.

"The main color of the moth is a very dark blue. There are three narrow, golden-yellow rings about the abdomen, as shown in the illustration. This golden color is also seen in the collar and on the inner sides of the legs, on the sides of the body under the wings, and to some extent on the wings themselves. The fore wings have some coppery marks, forming a sort of band near their tips, and are fringed and veined to a considerable extent with black and blue scales, presenting a beautiful appearance when examined in the sunshine with a glass of moderate power. The wings of the female expand about three quarters of an inch, but the male is considerably smaller. At the posterior extremity of the body there is an ornamental, feathery tuft of blue scales.

"The mischief done by the borer is shown by the poor crops of currants, both as to quantity and quality, and in the death of portions or the whole of the plants attacked. If neglected, so that the borers become numerous, they will frequently utterly destroy a plantation. In our garden, during the recent dry north winds, several large stalks showed the borers' work by withering, although they were covered with leaves and a moderate crop of fruit. Many twigs which were weakened have broken off under the weight of the new leaves.

"Dr. Harris speaks of instances in Massachusetts where all attempts to raise currant bushes from cuttings were baffled during the second or third year of growth by the ravages of these insects. Our currant raisers should take measures for their suppression before they become too numerous. 
"The remedy for the currant borer is to cut away and burn all those portions of the brush infested, during Winter or early Spring, before the insects escape. If a whole neighborhood unites in this action, the pest can be practically exterminated in one or two seasons.

"Among the other members of this family which do great harm, are distinct forms which attack respectively the peach and cherry, the grape root, the blackberry and raspberry, the maple, the squash vine, etc."

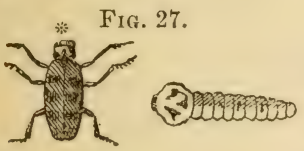

There is also another species of borer that infest the currant bushes, and is very destructive (Fig. 27), beetle and larva, natural size); this species is probably the Chrysobothris femorata, or closely allied to it; it also infests the apple tree. The remedies suggested by Mr. Dwinelle for the Aggeria tipuliforme are applicable to this species as well, and fully indorsed by Mr. W. H. Jessup, of Hayward, Alameda County, and Mr. A. T. Hatch, of Cordelia, Solano County.

We think if the trunks of trees, or canes of vines, infested by borers (or trees, etc., located near infested trees) were washed with either of the sulphur solutions (see Rule 1, page 11) just previous to the seasons for the deposition of eggs, the insect would not deposit the eggs on the part washed.

Notk.-For this purpose we prefer whale oil soap, and sulphur.

We are informed by an extensive fruit grower that his trees have not been infested by borers since he adopted the method of driving. about six iron nails into the roots of each tree just below the surface of the ground. (Any person wishing to investigate this method can get address from this office.)

Among the various kinds of insects injurious to fruit and fruit trees, the scale insects, or bark lice (Coccidx), should be the most dreaded by fruit growers. Within the last three years a great amount of damage has been done to orchard property in several sections of this State.

* The specimen from which Fig. 27 was made had lost its antennx. 


\section{SCALE INSECTS INJURIOUS TO FRUIT AND OTHER TREES.}

In writing of the different species of scale insects, we have not referred to their natural history, habits, etc., but refer the reader to the following paper by Prof. J. Henry Comstock, and to the report of Messrs. Chapin and Vestal, page 57:

Extract from a paper read by Professor J. Henry Comstock, Entomologist, Department of Agriculture, Washington, District of Columbia, at a meeting of the California State Horticultural Society, September 24th, 1880.]

There is no group of insects which is of greater interest to horticulturists to-day than that family which includes the creatures popularly known as "scale bugs." No variety of fruit is exempt from their attacks, and in certain localities many trees have been seriously injured, or even killed outright, by them. The oyster-shell bark louse of the apple, and several species infesting citrus fruits, are well known examples of these facts.

Notwithstanding the great importance of the subject, comparatively little thorough work has been done on the species of this country. This fact led me to undertake a serious study of the group, the result of which will be published as soon as practicable.

The object of the present paper is simply to give, for the benefit of California horticulturists, a few of the more important points in the life-history of scale insects, and a part of the results of my studies of the forms which occur on this coast.

The scale insects, or bark lice, comprise the family known to entomologists as the Coccidx. In many respects this is a very anomalous group of insects, differing greatly even from closely allied forms in appearance, habits, and developments.

The newly-hatched scale bug is oval in outline, much flattened, furnished with six legs, a pair of antennæ, and an apparatus for sucking the juices from plants. At this stage of its existence it is very small-a mere speck, which the untrained eye could only with difficulty detect. By means of a lens, however, they can be seen crawling in all directions over the leaves or bark of an infested tree. After wandering for a time, the young coccid settles on some part of the plant, inserts its beak, and begins its growth at the expense of its liost.

From this point the derelopment of certain species is quite strange, appearing to be a retrogression instead of an advancement to a more highly organized form, as is the rule in the derelopment of most animals. The skin it shed, and with it the legs and antennæ. The coccid thus becomes a degraded, grub-like creature, with no organs of locomotion. The mouth parts remain, however, in a highly dereloped state, and well fitted to perform their functions. This apparatus is not the least remarkable thing in the structure of these insects. It is terminated by a thread-like organ, which is frequently much longer than the body of the insect, and is composed of four delicate hair-like 
bristles. By means of this organ the insect is firmly attached to the plant, and draws its nourishment therefrom. From this stage the development of the sexes differ.

The female coccid soon moults a second time, and this shed skin is joined to that first moulted and forms a covering or scale, under which the insect is to pass its life. The moulted skins are. however, insufficient to cover the body of the coccid, which increases in size rapidly. To supply this deficiency a waxy matter is secreted by the insect, and successive additions thus made to the scale. 'The different modes in which these additions are made form some of the characters by which the different species of scale insects are most easily distinguished. For example: If the waxy matter is added to one side of the moults, and successive additions made to the same side, a long and more or less narrow scale is formed. The common oyster shell bark louse of the apple and the long scale of the orange, well known in Florida, are illustrative of this kind of scale insects. If the waxy matter be added to all sides of the moults, and successive additions are in the form of concentric rings, a circular scale is formed. To this group belongs the so-called "red scale" of this State, and a species which I purpose to call the Cuba scale, which occurs in a single grove in Florida, as well as the scale most destructive to fruit in the Santa Clara Valley. In each case the scale is nearly circular, and the moults appear at a point in the center. Numerous other forms of scales occur, but these are sufficient for our present purpose.

After the female reaches maturity the process of oviposition begins. The eggs are laid under the scale, the body of the female gradually diminishing in size as the eggs are laid, thus making room for them.

A word now respecting the development of the male. In the group of scale insects which I am now considering, the male scale can be ristinguished by its small size and the fact that but a single skin is moulted in the course of its formation. When the male bark louse attains its growth it changes to a pupa with rudimentary legs and wings; later it undergoes another change, and emerges from under the scale an active little creature, furnished with long legs and antennæ, and two large but very delicate wings. Its mouth and its appendages have disappeared, and in their place has been developed a second pair of eyes. Of course no nourishment can be taken during this stage of its existence, and its energies are devoted solely to the perpetuation of its kind.

\section{A SECOND GROUP OF SCALE INSECTS.}

A second group of scale insects differs from that just described, in that the species do not excrete a scale-like covering, composed in part of moulted skins, and the females preserve their legs and antennse throughout life. 'The form of the body of the female, however, usually changes greatly after impregnation. Of many species of this group the males are unknown, but in all the cases where they are known, they are winged, as in the first group. "The most familiar" representation of this group are the "black scale," or "brown scale," of this coast, and the "soft scale" of Florida. With the black scale, after impregnation, the body of the female becomes much thickened and elevated, assuming the well known characteristic form. After 
that, the sides and back of the insect become much hardened, and the minor part shrinks away from the plant as the eggs are laid. Thus there is formed a cup-like shell, or "scale," which covers the eggs and newly-hatched young. It should be borne in mind that this "scale" is the hardened body of the dead or dying female, and not an excretion separate from the body of the insect. This point is of practical importance, for it is easier to destroy a naked insect than one which is furnished with a water-proof covering like that of the scales of the first group.

\section{A THIRD GROUP OF SCALE BUGS.}

In the third group of scale insects the females change very little in form during their entire life, and do not become fixed in one place. The males are winged, as in other groups of coccids. 'The mealy bugs, so common in hot-houses, and the cochineal insect, are the best known examples of this group.

\section{SCALE BUGS OCCURRING ON THE PACIFIC COAST.}

These few remarks will give a general idea of the natural history of this family of insects. Now, as to the forms which occur on this coast: Up to this time I have studied fifteen species which infest cultivated plants in sufficient numbers to prove injurious. These will be described at length, with others occurring in the East, in a report which I am preparing for the Department of Agriculture. The most common species of this State is the "black scale," which is very abundant on citrus trees and olives, and also infests many other plants including the deciduous fruits. This agrees with descriptions of a common European species-Lecanium olcx-and I presume will prove to be the same. If this be true, the species was doubtless brought from Europe on citrus trees. Another very important species is that known as the "red scale.". This is as yet undescribed. I have, however, in manuscript, ready for publication, a description, including figures of different stages and both sexes. There is abundant proof that this species was introduced from Australia. These two examples are sufficient to show the danger of introducing pernicious pests with exotic plants. The same thing has happened in Florida. Although the two species just mentioned do not occur in that State, one very closely allied to the "red scale" has been introduced from Cuba. And another, the most common on orange in that State is an European species. All of these insects, however, are not foreigners. For example, there is an undescribed scale common on olive, pear, fig, and other trees in this State, which I have good reason to believe has spread in the cultivated trees from the native willows. And in Florida there is a scale which is quite common on citron trees and plants, which I believe has spread from the gall berry, an indigenous bush very common throughout that State.

HOW THE SCALE INSECT IS SPREAD.

A word as to the mode of spreading scale insects. As I have already stated, with most species the adult female is firmly attached 
to the plant upon which she lives; she is consequently a "stay-at-home body." And although the adult males are winged, it is obvious that the pests could not be spread by the flight of that sex alone. The newly hatched young of both sexes, however, are very active, crawling about from one part of an infested tree to another, or even to other trees which may be near. It doubtless often happens that these tiny creatures are brushed from the trees by persons or vehicles passing, and are thus distributed; or they may crawl upon the feet of birds, and thus be carried long distances. But the most common mode by which these pests are distributed is by the transportation of trees and fruit, infested with living scale insects.

\section{ME'THODS OF PREVENTING THE PEST.}

These facts suggest the following methods for preventing the occurrence of these nuisances. In planting an orchard choose as isolated a spot as is practicable. If isolation camnot be obtained, induce your neighbor to join you in efforts to grow clean fruit. Use the greatest care in the purchase of trees or importing buds. Before planting, thoroughly wash all such trees with an insecticide, even if they appear to be clean, for the untrained eye may fail to detect early stages of these insects. Do not visit infested orchards unnecessarily, and above all things do not carry home specimens of scale bugs as curiosities. Watch your trees carefully, and if one is ever found to be infested with scales, remember that no better investment can be made than to burn that tree, and that no time is so good for doing it as the day it is first found to be infected. The system of exchange of fruit boxes is a very dangerous one. Each shipper should have his boxes marked and insist on not receiving boxes belonging to other shippers.

\section{REMEDIES FOR EXTERMINATING THE PEST.}

In many cases, however, the pests have gained such a foothold that these methods of warfare are impracticable, and a remedy which will destroy these insects withont injuring the trees, is desirable. I have begun a large series of experiments with different substances, hoping to find such a remedy. These experiments are as yet incomplete, and I will only state, that so far I have found nothing more desirable, taking into consideration its value as an insecticide, its effect upon the tree, and its cheapness, than a strong solution of whale oil soap. This I apply with a fountain pump or garden syringe; and, as it is impossible, almost, to thoroughly wet every insect by a single application, several are usually necessary.

Many other substances have been tested, and the results of the experiments will be published as soon as practicable.

I will add, however, that I have scen most excellent results in the orchard of V.C. Mason, San José, from the use of the flowing mixture: One pound of concentrated lye, one pint gasoline, or benzine, half pint oil, five gallons water.

SMUT ON ORANGE TREES AND OLEANDERS.

Associated with certain coccids, and especially with those which 
(To not form a scale-like covering to the body, as has been already described, is a black substance covering the leaves and fruit. This is very abundant in this State on oleanders, oranges, and other plants infested by the black scale, and in Florida on trees infested by the mealy bug. It is popularly known as "smut." It is a fungus, and has been determined by Prof. Farlow, of Harvard, as Fumago salicina, a species which has long been known in Europe on olive and orange trees. It is a very serious pest, marring the appearance of plants, and in certain sections of this State, where it covers oranges, greatly reduces the market value of the fruit. An excellent paper on the natural history of this fungus has been published by Prof. Farlow, in the "Bulletin of the Bussy Institution of Harvard University," in which the following paragraph occurs: "The result of our examination of the diseased orange and olive leaves is briefly as follows: The disease, although first attracting the eye by the presence of a black fungus, is not caused by it, but rather by the attack of some insect, which itself deposits some gummy substance on the leaf and bark, or so wounds the tree as to cause some sticky exudation, on which the fungus especially thrives. It is not denied that the growth of the fungus greatly aggravates the trouble already existing, by so encasing the leaves as to prevent the action of the sunlight. TVe only say, that in seeking a remedy we are to look further back than the fungus itself-to the insect, or whatever it may be, which has made the luxuriant growth of the fungus possible."

My own observations confirm these conclusions. In fact, before I had read Professor Farlow's paper I had learned to consider the presence of fungus on the leaves as a sure indication of the presence. of scale insects. And as I had never been able to find the fungus organically connected with plants, but simply growing over the surface of them near the coccids, and easily removed by rubbing, I supposed that it grew upon the honey-dew which the insects excreted, and which so frequently attract the visit of the ants. This honeydew is doubtless the gummy substance which Professor Farlow observed. Professor Farlow suggests, as a means of destroying the fungus, the use of alkaline soaps as strong as the trees will bear. If our conclusions respecting the fungus be true this remedy will be a very effectual one, for it will destroy the scale insects which render its presence possible.

An interesting fact which I have frequently observed, is that where there is a luxuriant growth of this fungus it not only feeds upon the honey-dew but attacks and destroys the young coccid themselves. Thus, in some instances, I have found a large proportion of the young coccids on a leaf destroyed in this way, and when the remains of the insects were examined with a microscope the fungus was seen projecting in great quantities from them. At first thought this would seem to be a natural remedy. But I find that it is rare that coccids are destroyed except upon the upper surface of the leaves, where the fungus is most abundant. This is probably due to the lodging of the falling honey-dew chiefly on that surface of the leaves and the consequent confining, as a rule, of the fungus to that part, and there always remains a sufficient number of healthy coccid on the lower surface of the leaves to restock the plant. 


\title{
CLASSIFICATION OF THE COCCIDE,
}

\author{
BY IIONS V. SIGNORET, OF PARIS.
}

I. Diaspides-Species covered with a scale composed of successive moultings, and of a secretion forming a shield, or sack, more or less independent of the body of the animal. Nine genera are included in this sub-fanily, but the scales may all be reduced to two principal types, viz.: those with rounded shields, like an oyster shell, with the larval scale in the center; and those with more lengthened shiehls, in the form of a large comma, or of a large mussel shell, and having the larval scale at one end.

II. Brachyscelides-Species living in gall-like or tube-like excrescences. These insects are, so far as known, confined to Australia.

III. Lecanides-Species either naked or inclosed, or simply covered with waxy, calcareous, or filamentous secretions, and in which the female, after fecundation, generally acquires an entirely differently form to that which she previously possessed, and becomes fixed. Before pregnancy, they have the power to move, if necessary. A number of genera are included in this sub-family, some of which approaching in some characters to the Diaspides, have been separated by Targioni under the name of Lecanio diaspides.

IV. Coccides-Species retaining to the end the body form, with all its joints distinct. They never become necessarily fixed, and are either naked, or more or less covered with waxy or spumous matter, arranged generally in filaments.

\section{SAN JOSE SCALE INSECT.}

Aspidiotus perniciosus, Comstock. - This species of scale insect infests the apple, pear, peach, and plum trees, and is to be found on the bark, foliage, and fruit. It is very prolific, and very destructive. (See report of Messrs. Chapin and Vestal,* page 57.)

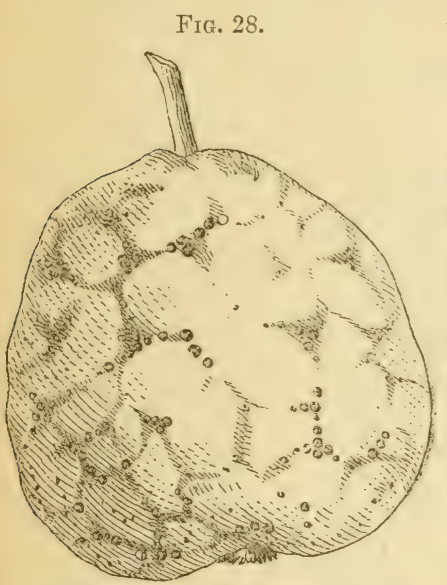

Fig. 28. Appearance of a pear infested by this species of scale insect.

FIG. 29. Fig. 29. Appearance of a FIG. 29. branch infested by this species

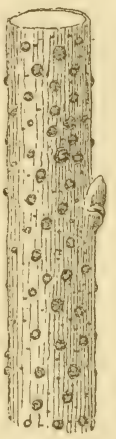
of scale insect.

Fig. 30 represents the matured female. The females are wingless, and in their last state deposit their eggs and very soon Fig. 30. perish - their

Fig. 30 .

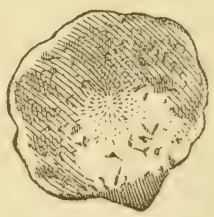
serving as a covering to the eggs. In speaking of the female of the Coccidx, Westwood says:

"That, without referring to their singular habits, we find some of them, on arriving at their last state, are not only wingless, but also footless and anten-

* We differ in opinion on one minor point of the natural history of this insect, but it is not material for the present purpose. 
næless, and in which even all appearance of annulose structure is lost-the creature, in fact, becoming an inert mass of animal matter. A slender setæ arising from the breast, and thrust into the stem, or leaf, or fruit on which the animal is fixed, being the only external appendage to the body."
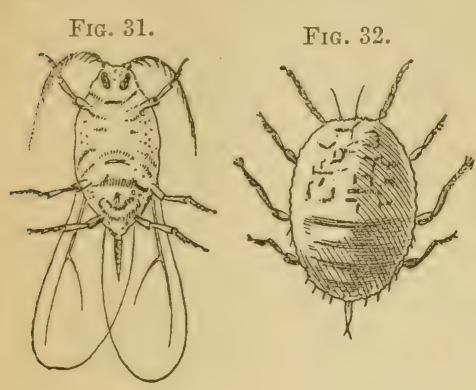

FIG. 32.

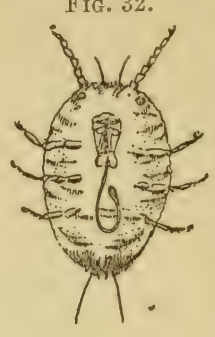

Fig. 31. Male insect (perfect), winged.

Fig. 32. Larva; Fig. 33, underside of larva. Description: Scale, about one sixteenth of an inch in diameter (scale of male insect elongated); color, center yellow, margin dark mottled gray; eggs, thirty to fifty produced by each female; color, yellow;

form, ovate; larva, six legs; two antennæ, six jointed; two anal setæ; body, color yellow; form, oval. Male

Fic. 34.

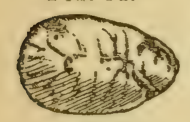

microscope). (Use remedies A, page 43.)

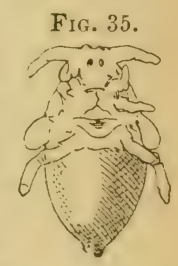

\section{SANTA CRUZ APPLE AND PEAR SCALE.}

Aspidiotus rapax, Comstock.-This species of scale insects can be found in Santa Cruz County, and also in some of the southern counties, on the apple and pear trees (Fig. 38) and their fruit, but is not considered so dangerous as some other species of the genus Aspidiotus. However, if we owned an orchard, there

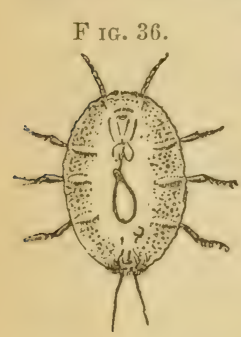

Male, winged. absence would be desirable to us.

Description of scale and insect:Scale, about one sixteenth of an FIG. 37. inch in length; form,

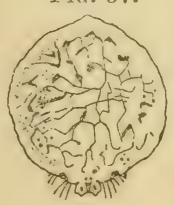
ovoid; color, drab. Larva (see Fig. 36), less than one one hundredths of an inch in length; two antennæ, six-jointed; two anal Fig. 38.

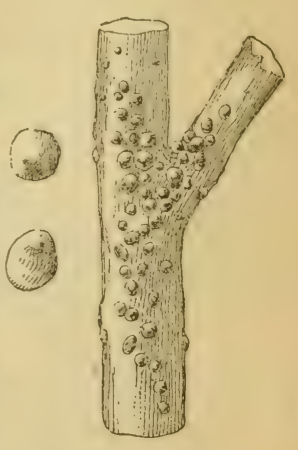
setæ. Female (Fig. 37).

(Use remedies A, page 43.) 


\section{WHITE SCALE (OR ROSE SCALE).}

Fra. 37⿱亠䒑䶹2. Diaspis Rosæ (or closely allied to it).-This species can be found in many gardens in this State, and has shown a tendency to spread on vines in certain districts, especially those of the raspberry and blackberry.

Description of scale and insect:-Scale, one tenth of an inch in diameter; form, irregularly round, slightly convex (Fig. 37 $\frac{1}{2}$ ); color, white. Larva, length, one one hundredth of an inch; color, reddish. Eggs, twenty to thirty-five under each scale; color, yellowish red. Female (Fig. 37 $\frac{3}{4}$ ). Male, winged. (Use remedies B, page 43.)

To protect the raspberry and blackberry crop this pest must be exterminated.

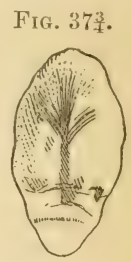

\section{BLACK SCALE.}

Lecanium Olex.-This species of Lecanium is more generally found in the orchards and gardens of this State than any other species of the Coccidx. It can be found upon nearly every species of the deciduous fruit trees, and every species of the citrus trees, and also upon many species of ornamental trees and shrubs, and is very prolific.

The foliage and fruit of trees infested by the black suale, Lecanium Olex, are also infected by a black substance, said to be a fungus growth, which is generally formed on the upper part of the leaves and fruit as they hang upon the branches. It is claimed by some persons that this scale exudes a honey or dew, which falls upon the fruit and foliage, and coming in contact with matter in the air forms a fungus growth. Others claim that the attack or bite, made by the insects on the branches and leaves, causes the leaves to exude a honey or dew, which coming in contact with matter in the air, creates a fungus growth. However, it is generally conceded that this black matter is in some manner caused by the presence of this black scale insect. It certainly injures the tree by preventing free FIC. 39 . respiration, and injures the sale of citrus fruits, on which it is found. It is also injurious to deciduous fruits for canning purposes.
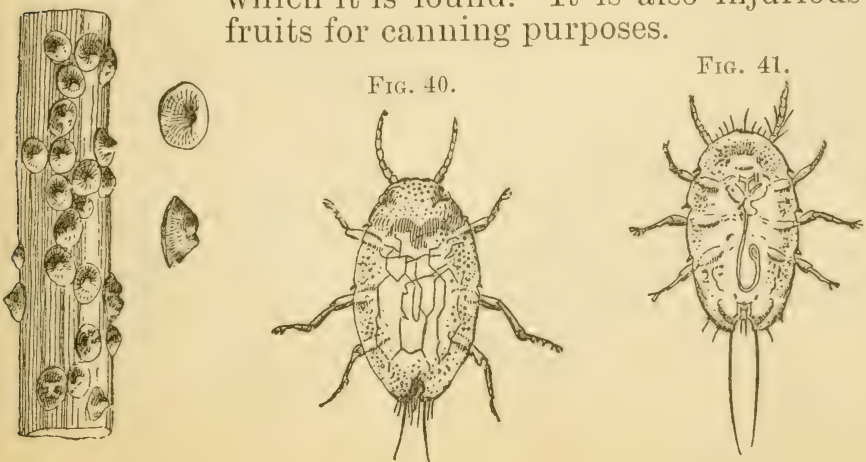

Frg. 42.

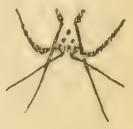

Fig. 43.

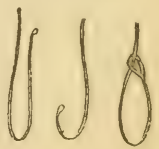


Description: Scale, (Fig. 39) length, from one eighth of an inch to one fifth of an inch ; form, ovoid; color, at first formation, greenish brown; when half grown, reddish brown; and at maturity, black. Eggs, from seventy-five to one hundred and twenty-five under each scale; color, when first formed, whitish; before hatching, a reddish yellow. Larva, (Fig. 40) length, one ninetieth of an inch; color, pale reddish yellow. Form, ovoid. Antennæ (Figs. 40 and 41), seren jointed, indentation on posterior end; two anal setæ on posterior angles of indentation, and two at inner angles of indentation. (Use remedies C, page 44.)

Noтr. - The black scale on the olive, peach, apricot, citrus trees, and garden plants, resemble each other in appearance to the unaided eye, but on examination of larvæ under a microscope, they differ somewhat in description. Fig. 40, larva of Lecanium on peach tree. Fig. 41, larva of Lecanium on garden plant and elm. Fig. 42, setae at inner angle of indentation of Fig. 41, the larva of Lecanium on elm and locust resemble closely the larva of cottony grape scale, Lecanium acericola, etc. (Fig. 57). Fig. 43 shows what appears to be an intestine in larvæ of scale insects, each species having a different form, and shows the form in some species (not illustrated in these pages), especially of Lecanium. We hope, in a short time, to be able to. describe this portion of the insect's anatomy.

\section{BROAD SCALE OR SOFT ORANGE SCALE.}

Lecanium Hesperidum, Linn.-This scale (Fig. 44) is one of the largest of the genus Lecanium that is found on fruit trees. Its food

FIG. 44 .

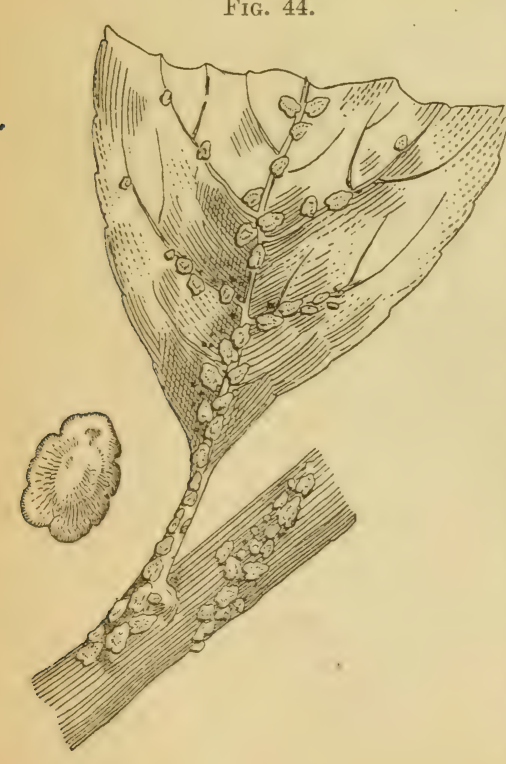

plants are principally citrus trees, and it can be found on the young growth, leaves, and fruit of trees infested. A few species of deciduous and ornamental trees are also infested by it.

Description of scale and insect:Scale, ovoid, a little wider at one end than the other; length from one tweifth to one seventh of an inch; color, dark brown on convex part, and a lighter brown surrounding margin; it has two indentations on each side, and one on posterior end; eggs, from seventy-five to one hundred and twenty-five under each scale. Larva: Length, about one nineteenth part of an inch; color, yellowish, slightly mottled; seven-jointed antennæ; two anal setæ as long as body. The viscera can be readily seen through the scale while maturing; color of viscera, yellowish red; male, winged. (Use remedies C, page 44.) 


\section{OYSTER SHELL BARK LOUSE, OR COMMON APPLE SCALE.}

Aspidiotus conchiformis, Gmelin; Mytalaspis pomicorticis, RileyDescription of Fig. 45: 1. Egg; 2. Young insect (larva); 3. Appear-

Fig. 45 .
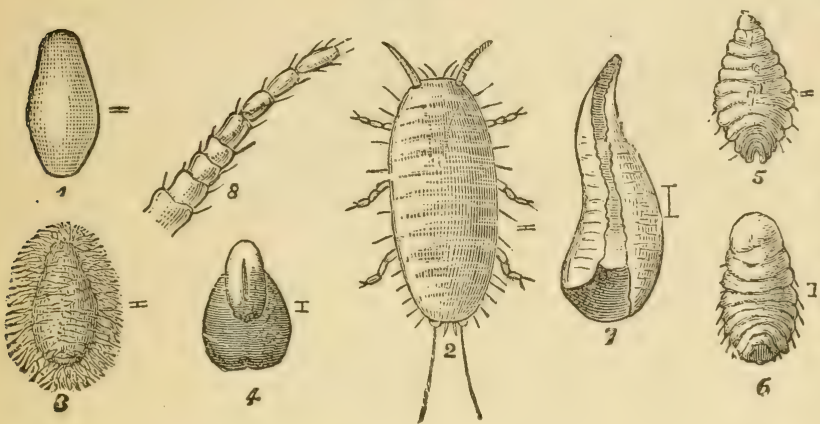

ance of secretion as it hardens and forms shell over body of insect; 4 . A form of the scale before it reaches maturity ; 5 and 6. Appearance of insect after casting skin, limbs, and other appendages; 7. S'cales (cover) at maturity; 8. Antennæ. All of these figures highly magnified. Description of insect, etc.: Eggs, number under each scale thirty to seventy-five; length, one one hundredth of an inch; form, irregularly ovoid; color, snow white, when near hatching, yellowish. Larva: Length of body, one one hundredth of an inch; form, ovoid; three times as long as wide; color, Fig. 46.

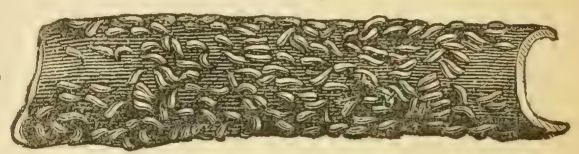
pale yellow. Antennæ, sometimes six-jointed, but generally sevenjointed. Anal setæ, two, about two thirds as long as body. Male insect (perfect): Length, one forty-fifth of an inch; color, flesh colored gray; abdomen and thorax, about same length as seen from above; wings, nearly transparent. "The last joint of abdomen narrowed into a large tubercle bearing four bristles on the under side, and sending forth the genital armor in the form of an awl-shaped stylet as loing as abdomen." This scale (Fig. 46) can be found on nearly all deciduous fruit trees in districts infested. (Use remedies A, page 43.)

\section{ASPIDIOTUS CITRICOLA.}

Fig. 47.

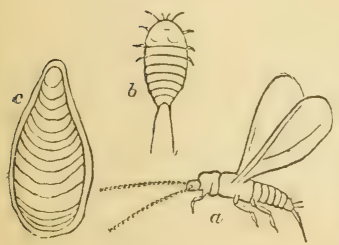

On Tuesday, September 20, 1881, there was received in this city (Sacramento), a shipment of oranges and lemons from Australia, which were infested by scale insects-the oranges apparently by Aspidiotus aurantii, or red scale; the lemons by Aspidiotus citricola. Fig. 47: (a) male insect; $(b)$ female, or larva; $(c)$ scale. The insects are apparently in a healthy condition. An additional pest may be added to the catalogue of scale insects by this shipment. Description of Aspidiotus conchiformis will be sufficient for this scale for present purposes. 


\section{COTTONY CUSHION SCALE.}

Iceryia purchasi, Maskell - This species of scale insect has infested an orchard in Santa Barbara County to a serious extent, and can be found on the orange, lemon, fig, and apple trees. If allowed to spread from the locations already reported, we have no hesitation in stating that it can only be exterminated at an immense outlay of labor and money. We are informed that this species of scales is to be found in a garden in Los Angeles, and that it has done some damage to ornamental trees at San Rafael, in Marin County. Our opportunities for investigating the natural history of this insect have been limited; but, from what we have learned of its habits, etc., we advise that whenever this pest appears it shall be exterminated regardless of cost.

FIG. 48.

Description: Fig. 48, natural size; length, about one half of an inch; greatest anterior width, about one fifth of an inch, narrowing gradually posteriorly; the anterior end is of a denser color (Fig. 48), and represents the matured insect (or larva); the rest of the body of Fig. 48 is composed of a cottony excressence of a yellowish white color and marked with longitudinal corrugated bars, giving the insect somewhat the appearance of a beetle, as seen on the tree; in the cavity of the cottony mass are deposited the eggs, from two hundred to five hundred in number; color, pale red; form, elongated ovoid. Larva: (Fig. 49) length, one

FIG. 49.

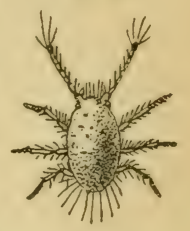

FrG. 50.

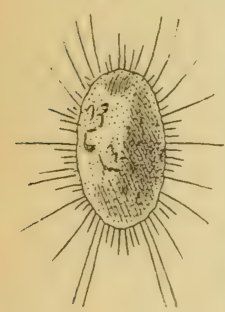
twenty-fifth of an inch; body, red; long bristling hair growing from posterior edge; two antennæ, color, black; six-jointed; (apex) clubbed, with long hairs growing on club-joint; six legs, color black, and spined. Larva matured: (Fig. 50) Nearly one fourth of an inch in diameter; ground color, reddish brown with yellow and white cottony markings, with long hairs extended. For general appearance of insect at maturity, see Fig. 48 ; and for larva at maturity, see Fig. 50. Fig. 51 represents this pest on a branch. This insect is accompanied by smut on the branches and foliage, as described in the article on black scale. Male, winged; color, body red; long antennæ; wings, color, light brown. (Use Fig. 51, remedies D, page 44.)

\section{RED SCALE, LOS ANGELES.}

Aspidiotus aurantii, Maskell-This species of aspidiotus has infested several citrus orchards in one district of Los Angeles County to a serious extent. It has been claimed by residents of other districts of the county, that it is only to be found in the locality referred to, but such is not the case; we have found it in some other districts of the county, though not to any serious extent as yet. It has lately been found at Marysville, Yuba County, on a few trees. Only the strictest 
attention to quarantine rules and regulations will keep it from spreading to every citrus orchard in this State.

Description of scale and insect:-Scale, matured, one twelfth of an inch in diameter (in a few cases it exceeds this); color, center yellow, margin light brown; eggs, from twenty to forty under each scale; form, ovoid; color, bright yellow. Larva: Length, one hundredth of an inch ; form, ovoid ; color, bright yel-

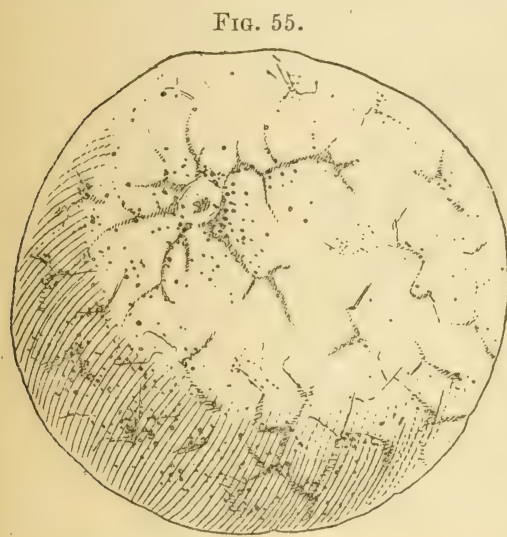

low; antennæ, six jointed. Female insect, color, yellow (see Fig. 52). Male insect (perfect), winged (Fig. 53), about one
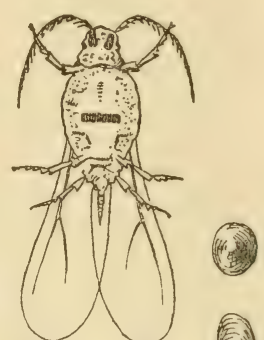

forty-fifth of an inch in length; wings clear, nearly transparent; color of body, amber yellow with slight dark markings; anal stylet appendage nearly as long as body.

It feeds upon the foliage (Fig. 54), and fruit (Fig. 55), covering the fruit to such an extent as to unfit it for sale in the market. (Use remedies $\mathrm{D}$, page 44.)

\section{SCALES FOUND ON ELM AND LOCUST TREES, ETC.}

We have found that the elm trees (especially the cork elm) and locust trees, in the City Hall Park, in Stockton, and also

FIG. 56.

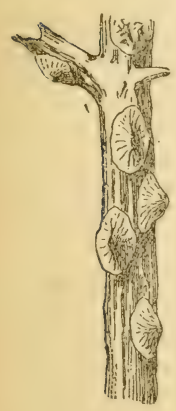
many shade trees on the streets, are infested by a large scale (Lecanium). It is also reported that some orchards on the islands below Stockton are infested by scales. Those who own fruit trees cannot be too particular in watching for scale insects, as a great deal of the damage done by them can be attributed to their introduction on ornamental trees. The authorities of the City of Stockton, or the Supervisors of San Joaquin County, should attend to the matter of abating the nuisance.

Description of insect and scale: Scale (Fig. 56), one eight to three sixteenths of an inch in length; form, oval; color, brownish black; eggs, from two hundred to three hundred under each scale; color, yellowish white. Larva, one ninetieth of an inch in length; scalelike; form, elongate ovoid; antennæ, seven-jointed. (See Fig. 40. Use remedies A, page 43.) 


\section{COTTONY GRAPE SCALE.}

This scale is of the genus Lecanium, closely allied to the Lecanium macluiae, or Lecanium acericola, or maple leaf scale. This scale is

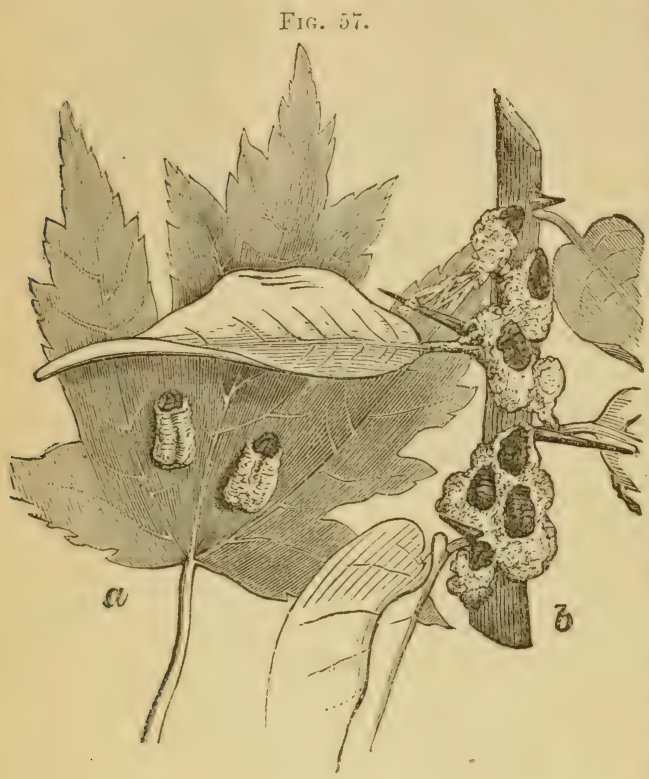
found on several vines in Santa Barbara County. The scale proper is about one eighth of an inch in diameter, of a bluish color. It produces a cottony cover for its eggs and young. The eggs are white and scale-like, about one ninetieth of an inch in length; form, ovoid; has much the appearance of the young of other species of the Lecanium; color, whitish yellow; two antennæ and anal stylets. Only one vineyard has been reported thus far, but it is found in several arbors in the town of Santa Barbara. (Fig. 57.)

We have specimens of this species of scale insect on grapevine prunings in our office, found in a garden at Sacramento. (Use remedies D, page 44.)

\section{MEALY BUG.}

Dactylopius adonidum, Linn.-This species of the genus Coccides may be said to be a universal pest of the hothouse. It is also found in the gardens, nurseries, and citrus groves.

Description: Male insect, similar in appearance to Fig. 60 (except-

FrG. 58.

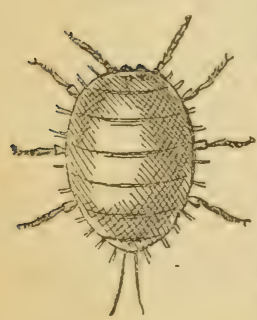
ing form of abdomen); he has two long filaments protruding from anal segment rings, instead of the anal stylet in some other species described in this work; length of insect, from one twentieth to one twenty-fifth of an inch; wings, nearly transparent; color of body, brownish yellow. Female, full grown (Fig. 58): length, about one seventh of an inch; color, yellowish white; two antennæ; two anal setæ, nearly half length of body; a fine, mealy-like substance covers the body, hence the name. Larva, when hatched, about one fiftieth of an inch in length; color, yellowish white. Eggs deposited on leaves, etc., and covered by a cotton-like substance.

This pest is very prolific, and brings forth its young, or broods, at 
all seasons of the year. Remedies which destroy other species of scale insect have no effect on the mealy bug. Howerer, the danger of its spreading is such that it should be exterminated wherever found, regardless of cost.

Remedies: Mr. Ashmead writes: "The usual methods seem to have no effect. I would, therefore, recommend kerosene, diluted with three parts of water" This should be syringed over the plants infested. Great care should be taken to shake the wash well before applying it, for unless this is done the oil will rise to the top of the water, and wherever pure kerosene is ejected upon the tree the leaves and twigs are sure to die."

To obviate the trouble of shaking, etc. of the wash recommended by $\mathrm{Mr}$. Ashmead, we recommend one quart of kerosene mixed with three fourths of a pint of any animal oil.* In three quarts of water, dissolve three fourths of an ounce of borax. Then mix all together, and a solution will be produced, thoroughly mixed and ready for use.

\section{SCALE INSECT ON THE NORFOLK ISLAND PINE.}

Uhleria araucarix, Comstock.-This species of scale insect is only found on the Norfolk Island pine (specimens from Santa Barbara).

Description: Scale, one

Fig. 59. sixteenth of an inch in diam-

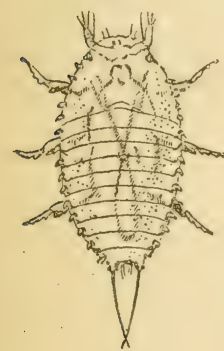
eter; form, irregularly round; color, white. Larva (Fig. 59), length about one one hundredth of an inch; color, light amber: two antennæ; two long anal setæ-appears to be covered with very fine, armorlike plates or scales. Female - color, yellow. Male-color, dark brown; wings nearly transparent; antennæ ten

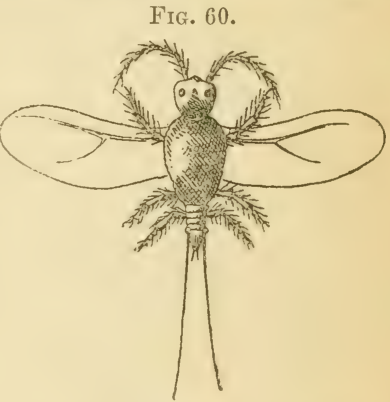

jointed; two long filaments protruding from anal segments, instead of the anal stylet in some species described in this work. (Use remedies $\mathrm{B}$, page 43.)

CURRANT BUSHES AND GRAPEVINES INFESTED BY SCALE INSECTS.

A species of scale insect of the genus Aspidiotus is found on the currant bush, and also on the grapevine; by use of remedies B, page 43 , the pests can be destroyed.

* Neats foot oil, lard oil, or whale oil. 


\section{ORNAMENTAL TREES, ETC., INFESTED BY SCALE INSECTS.}

We find in various sections of the State, that many varieties of trees and plants, such as the acacia, bay tree, manzanita, oleander, willow, osage orange, etc., are infested by scale insects, and nearly all belonging to the genus Aspidiotus. All such trees infested by scale insects should be thoroughly cleansed, by washing or spraying, as soon as the scale insects appear on them.

\section{Remedies.}

For large trees, use remedies B. (Page 43.)

For plants or shrubs, etc., use remedies D. (Page 44).

\section{LYE MADE FROM WOOD ASHES.}

It is generally estimated that one bushel of good wood ashes will produce five pounds of potash. TVe are informed by Mr. and Mrs. Roberts, of San Bernardino (old), San Bernardino County, that the ashes of cottonwood produce more potash than any other kind of wood ashes. In making washes for trees from wood ashes, we think it would be safe to estimate five pounds of potash per bushel of goord ashes, if thoroughly leached.

\section{FIGHTING THE BLACK SCALE.-Lecanium oleæ.}

Ellwood, the residence of Ellwood Cooper, Esq., is situated about fourteen miles north of Santa Barbara, in Santa Barbara County. This tract of land contains very fine orchards of almond, walnut, and olive trees. The olive trees became infested with the black scale, Lecanium olex, and Mr. Cooper saw at once that if they were allowed to remain on the trees, making a choice oil would be impossible, so he began the work of extermination, and carried it on zealously until he was rewarded by complete success. In one small orchard, containing about one hundred trees, he cut off the limbs and washed the trunks thoroughly with a solution of whale cil soap. The balance of the three thousand five hundred bearing trees he washed with a decoction of tobacco, and in some instances, when necessary, he swabbed the part with pyrolyneous acid. Some of the trees were simply washed with whale oil soapsuds.

Mr. Cooper grows tobacco for this purpose, at a cost of one and one half to two cents per pound. Thirty pounds will wash one hundred trees. Mr. Cooper applied the wash at a temperature of one hundred and thirty degrees Fahrenheit, and found that it did not injure the foliage or blossoms. Let those who doubt that the black scales can be exterminated, examine the olive groves at Ellwood before they become grounded in opinion. 


\section{GENERAL REMEDIES.}

A.

Remedies for cleaning Apple and Pear Trees infested by Scale Insects, Aspidiotus perniciosus, etc. A. rapax and A. conchiformis.

Make a solution of one pound of commercial concentrated lye, or one and a third pounds of commercial potash to each one and a half gallons of water. (See ash lye, page 42). The lye or potash should be melted or dissolved in boiling water. Before pruning the trees, wash or spray them thoroughly with a solution, proportions as above, and if possible at a temperature of one hundred and thirty degrees Fahrenheit.

The limbs and branches should be thinned out sufficient to give free access of light and air to the foliage, etc., on all parts of the trees. The prunings should be burned, immediately after being taken off the trees. After pruning, providing the trees are not in bloom, wash or spray the trees with a solution, of one pound of commercial concentrated lye, and one and a third pounds of commercial potash to each two and a half gallons of water. (See ash lye, page 42.)

If the trees are in bloom, wash or spray with either of the sulphur solutions recommended in Rule 1, page 11.

If a Summer washing is necessary, use either sulphur solution. See Rule 1, page 11; it will not injure the foliage or fruit.

Noте.-If apple or pear trees are very badly infested, the solution may be used: one pound of concentrated lye, or one and a third pounds of commercial potash to each one gallon of water.

Satisfactory results will depend upon the manner in which the washing or spraying is done.

B.

Remedies for cleaning Peach, Plum, and other varieties of Trees producing stoned fruit, infested by Scale Insects. Aspidiotus perniciosus, A. rapax and $A$. conchiformis.

Make a solution of one pound of commercial concentracted lye, or one and a third pounds of commercial potash to each two gallons of water. Wash or spray thoroughly with this solution before pruning. For second washing, if before the trees bloom, use same amount of lye or potash to three gallons of water. If in bloom, or bearing fruit, use sulphur washes recommended in Rule 1, page 11. If the trees are only infested by black scale, Lecanium olex; see article "Ellwood," page 43, or use treatment C, page 44. 
C.

Remedies for cleaning Olive, Peach, Plum, and other deciduous and ornamental Tirees and Plants infested by Black Scale, Lecanium oler, and Soft Orange Scale, Lecanium Tesperidum.

One pound of commercial concentrated lye, or one and one third pound of commercial potash, dissolved in two gallons of water. TVash or spray with a solution of the above proportions before pruning. After pruning and before the tree puts forth the fruit blossoms; wash or spray with a solution, containing same amount of concentrated lye or potash as above, dissolved in three gallons of water. If a third washing is required during the Summer, use either of the sulphur mixtures recommended in Rule 1, page 11.

For cleaning citrus trees of black scale or soft orange scale, use remedies D, page 44 .

\section{D.}

Remedies for cleaning Citrus Trees infested by Aspidiotus aurantii, Lecanium oler, Lecanium hesperidum, Diaspis roser, and Fumage solicina (i.e.smut).

To procure the aid of nature to assist in exterminating the scale insects, smut, etc., infesting citrus trees, should be the ambition of every citrus-grower.

First-At a season of the year before the trees bloom, make a solution of one pound of Commercial concentrated lye to three gallons of water, and thoroughly wash or spray all the foliage of the tree. If practicable the washes should be applied at a temperature of $130^{\circ}$ Fahrenheit.

Second-After using this wash as directed, thin out the branches by pruning, so that the air and light may have free access to the foliage and fruit on the tree. The branches left on the tree should not be allowed to reach near the ground.

Noтк.-We have examined leaves of orange trees sent us by Mr. A. B. Chapman, of San Gabriel, Los Angeles County. Mr. C. has made strenuous efforts to destroy the red scale by: washing, etc. On sixty-three leaves examined, seventy-one per cent. of the seale insects were destroyed on the upper side of the leaves, and thirty-seven per cent. on the under side of the leaves. The density of the foliage on the trees prevented the washing from being more effective.

Third-All prunings and foliage taken from the trees should be destroyed as soon as possible, then repeat the washing or spraying as above.

Fourth-About three weeks after pruning, or as soon as the larva of the insect appears, wash or spray with either of the sulphur solutions recommended in Rule 1, page 11.

Fifth-The fourth washing may not be necessary; if it should be, repeat No. 3, as it will not injure the foliage or the young fruit. Mr. G. M. Holmes of Orlando, Florida, writes that for the destruction of a scale insect, Chrysomphalus ficus (similar to the Red Scale), he had "been most successful in the use of a strong brine of salt and water 
applied twice, at intervals of two weeks. It is heroic treatment, and takes the leaves off, but the scale comes with them, and if done just prior to a growing season, they soon send out a luxuriant new growth and seem more healthy than before. I think if potash were mixed with salt and water it would be an improvement, and I am going to use it in that way."

Sixth-The solution recommended will clear the foliage, fruit, and branches, of scale insects, smut etc., if properly applied.

Seventh-The foliage should be thoroughly saturated in the first washing, so to remove the smut.

Eighth-For immediate extermination of the red scale, $A$. aurantii, on citrus trees, we think if the foliage is thoroughly washed or sprayed with a strong brine of salt and water, to which add one pound of concentrated lye to each three gallons of brine, and, if necessary, repeat the washing as directed by Mr. Holmes. It will take off all the foliage and scale, which should be carefully gathered and destroyed by burning. This is certainly worth trying. An orchard can be cleaned in this way by operating on the trees most exposed to the winds, etc. It is preferable to the method of cutting away all limbs of the tree above the crotch, as practiced by some growers.

\section{COTTONY CUSHIUN SCALE.}

Iceryic purchasi, Maskell-Use same remedies (D) as for red scale, Aspidiotus aurantii, Maskell, on citrus trees. -(Page 44.)

WHITE SCALE ON RASPBERRY VINES, ETC.

Dicspis rosx-Use same remedies (D) as for red scale, Aspidiotis aurantii, on citrus trees. (Page 44.)

OLIVE TREES.

For black scale, Lecanium olex-Use same remedies (C) as for peach, plum, etc. (page 44), or see article "Ellwood." (Page 42.)

\section{ORNAMENTAL TREES IN GARDENS.}

Use same remerios (D) as for red scale, Aspidiotus aurantii, on citrus trees. (Page 44.)

ELM TREES, ETC.

Use same remedies as for apple and pear (A), Aspidiotus perniciosus, etc. (Page 43.)

COTTONY GRAPE SCALE.

L. arcericole, etc.-Use same remedies (D) as for red scale, Aspidiotus aurantii, Maskell, on citrus. (Page 44.) 
PUMPS FOR WASHING TREES.

Experience has taught us that the most effective remedies for the Frg. 61. extermination of insects injurious to fruit and fruit trees, especially those belonging to the Coccidx, are

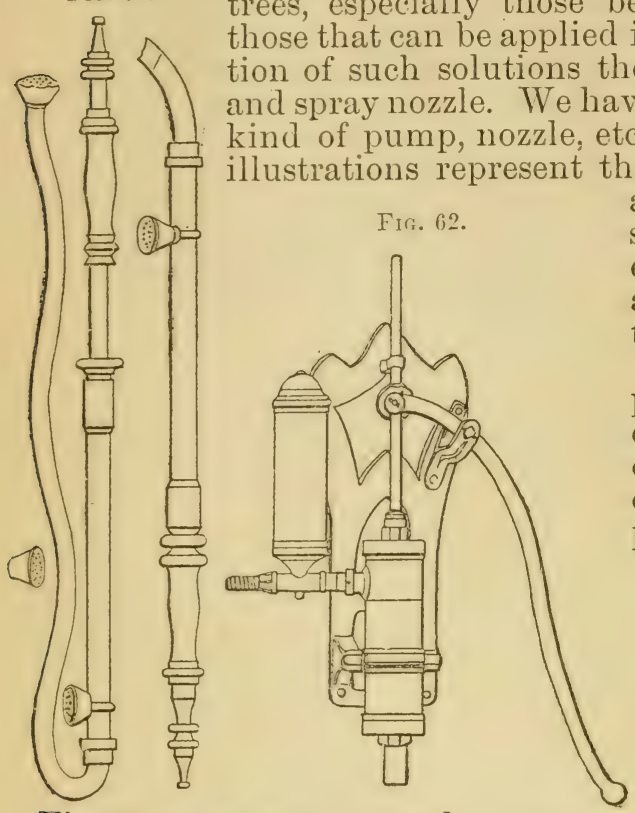

Fig. 63 represents a nozzle, manufactured at San José, which we will call the San José nozzle. A is a diaphragm with a small opening in center of any required size. This is placed on the piece $B$, on top of screw; the cap, C, is then screwed on, and the nozzle is complete. With a force pump this throws a very fine spray over the tree. A full set of diaphragms are sent with Fig. 63. each nozzle.

Fig. 64 is known as the Niagara lawn sprinkler, and is manufactured at Sacramento. Through the concave cone, A, is placed a rod, C, with screw thread cut on top. On this is placed an inverted cone, B, by which the spray can be regulated to any desired quantity, as shown in Fig. 65. Either of the above nozzles placed on a hose, or pipe, attached to a pump, will work economically. present. Fig. 61 represents a fountain pump; the end of the hose is placed in a barrel or pail containing the fluid; price, $\$ 750$.

Fig. 62 represents a force pump, which can be placed on the top of a barrel, and is capable of throwing a spray over any ordinary fruit tree; price, \$17.

FIG. 64 .

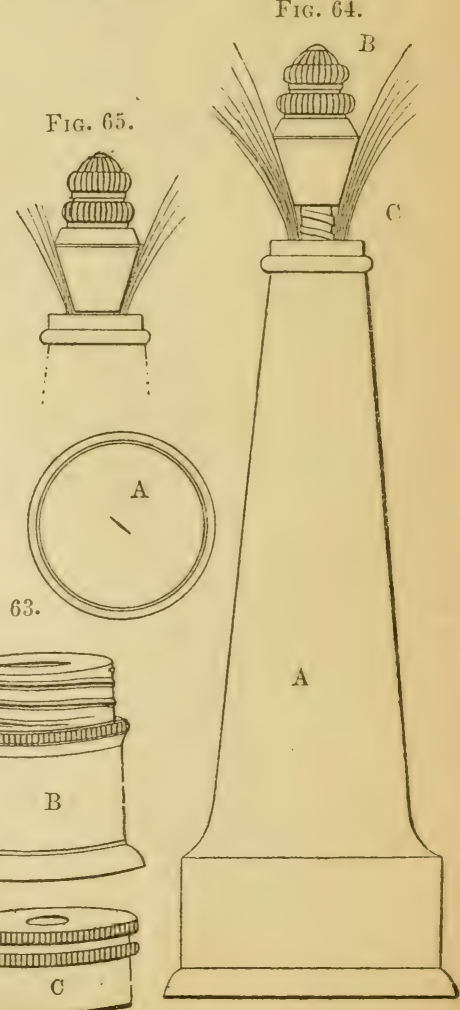


Mr. D. C. Vestal, of San José, states that one hundred of his pear trees, nearly twenty years planted, can be washed each day by pump and nozzle.

Last Winter we made some experiments, by applying the solution to the trees by means of a jet of steam and a syphon pump, which gave very good results. Where a large orchard is to be cleaned, we think the steam, either by syphon pump or by pressure, is the cheapest and best, as the wash can be applied at any temperature required, and any reasonable number of hose can be attached for expedition of the work. 


\section{NATURAL REMEDIES.}

Lady-birds, or Lady-bugs (Coccinellidx).-The "lady-birds" are better known, perhaps, than any other family of beetles. They are small, round, and hemisplierical, usually red, yellow, or black, with spots of one or the other of these colors. All are carnivorous, except Epilachna. The eggs are usually long, yellow, and oval, and are laid in patches, often in the midst of a group of plant-lice, which the newly-hatched larvæ greedily devour. The larvæ are long, soft-bodied, rather pointed toward the end, and are quite active. The jaws are small and inconspicuous. They are often quite gaily colorer, and eovered with scattered tubercles, spines, or tufts of hair. They attain their full growth in three or four weeks. When about to transfrom to pupæ they attach themselves by the end of the body to a leaf or twig, and either throw off the old larva skin, which remains around the tail, or retain it around the pupa for protection. The pupa is small and rounded, simulating the true beetle. The perfect insect comes forth in about a week. The larvæ feed upon plant-lice and 8ther small insects, of which they destroy immense numbers. The adult beetles also destroy other insects, although in lesser numbers than the larvæ. Quite a number of species of the lady-birds are found in the orchards doing good work, a few of the most common of which we figure and briefly describe.

Coccinella novemnotata, Herbst (Fig. 67), is lighi yelFIG. 67. lowish red in color, and may at once be distinguished by the nine black spots upon its wing-covers, arranged as shown in the figure, four upon each wing-cover, the two hind ones being the larger, and one in front on the middle line. Coccinella munda is a smaller species of precisely the same color, but without any spots upon the wing-cover. Its thorax is black, with two small light spots. Hippodamia convergens resembles the preceding in general ground color. It is larger and more elongated. On the wing-covers are thirteen small black spots. The thorax

Fig. 66 is black, with a light yellow margin, and two lines of the Fa. 66. same color approaching a V in shape. Hippodamia maculata (Fig. 66) is pink in color, with ten large black spots on the wing-covers, of which two are upon the middle line. The thorax is pink, with two large black spots, and the head is pink, with black eyes. It is smaller than the last named species. Coccinella venusta is larger and broader. It is pink in color, with ten large black spots upon the wing-covers, of which the hind two blend into each other across the middle line. The inner middle spots are shaped like inverted commas. The thorax is pink, with four black spots, of which the two hinder ones meet across the middle line to form a V. Chilocorus bivulnerus, Muls. (the twice stabbed lady-bird), is hemispherical in form, and shiny black in color. A little in front of the middle of each wing-cover is an irreg- 
ular bright red spot. The thorax is black, with a whitish border, and the head is whitish, with black eyes.

We describe the only vegetable-feeding lady-bird in order that those interested may know what it is, and not consider it a beneficial species. It is known as Epilachna borealis, Thunberg. It is much larger than any before mentioned, is of a light reddish vellow color, witi seven large black spots upon each wing cover. The thorax is of the same color, and has four small black spots. The head is concolorous with the thorax, and the eyes are biack. Both the larvæ and perfect insects feed upon the leaves of cucumbers, melons, squashes, and pumpkins-eat unsightly holes in them, and, when numerous, completely destroy the plant. Another beetle, of injurious proclivities, is often mistaken for a lady-bird by the planters, although it belongs to an entirely different family. This is the

FIG. 68. twelve-spotted Diabrotica, Diabrotica duodecim-punctatu, Fabr. 'This insect is shown in Fig. 68, and certainly does resemble Coccinella to the untrained eye. The principal points of difference between it and the common Hippodamias, which it most resembles, are that the Diabrotica is usually greenish, varying occasionally to yellowish, that it has twelve black spots arranged in parallel rows down the wing covers, and that the thorax is green and unspotted. The twelve-spotted Diabrotica belongs to the family Chrysomelidre, or leafeating beetles. Dr. Packard states that they devour the leaves of dahlias, and they are commonly found gnawing melons, squashes, and cucumbers. (U. S. Agricultural Reports, 1879.)

FIG. 69.

Diabrotica vitata (Fig. 69) is also destructive to plants.

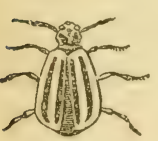

Aphis lions, Chrysopa.-The aphis lions are the larvæ of the "golden-eyed lace-wing flies"-insects with slender bodies and extremely delicate, gauze-like wings. Their color is usually green, and their eyes golden (represented in all stages, Figs. 70 and 71). Upon being disturbed they emit a disagreeable, fetid

FIg. 70 .

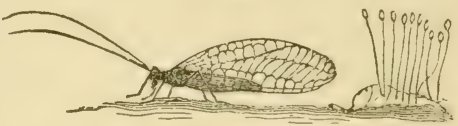
odor. Their eggs are white and are supported by long footstalks, as shown in the figure, usually upon plants infested with plant-lice. The larvæ are active and extremely voraFIG. 71. cious. There are two or more broods in the course of the Summer, and the last brood winters in the chrysalis state, protected by a compact, round, whitish cocoon.

FIG. 72.

Spined tree bug. Podisis (Arma) spinosus, (Fig. 72.)-

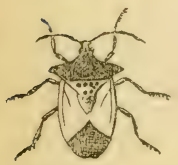
A brownish or grayish plant bug, nearly the color of tree bark - several specimens have been brought to our office by parties finding them on their trees, thinking they were injurious to fruit, etc. This insect injures the leaves of apple and other trees by sucking the sap. However, it is reputed to be very destructive to the larva of the Colorado potato beetle and gooseberry saw-fly. It may be more of a friend than enemy of the fruit grower. 


\section{APHIDE.}

Aphidx-(Fig. 73 and explanation.) This family of insects (plantlice) are perhaps the greatest enemies of the vegetable world. Nearly three hundred species are described. It was formerly a great

FIG. 73.

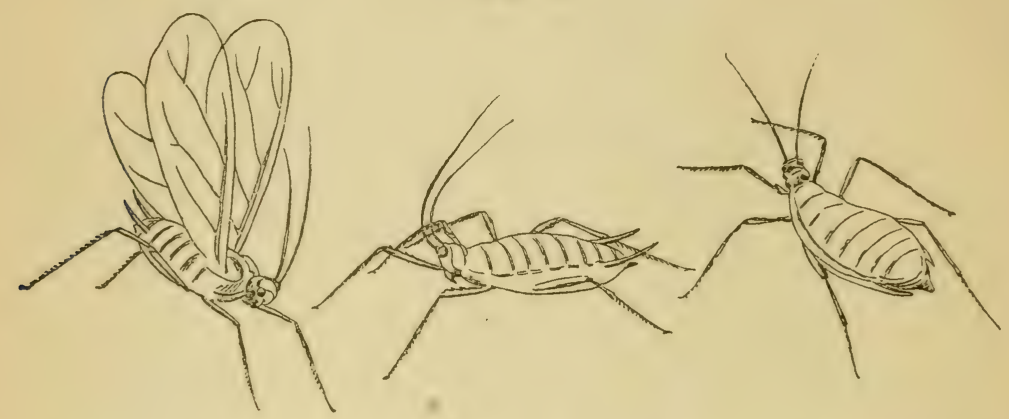

puzzle to understand, or to account for, the rapid increase of the plant-lice, and the question has been carefully entertained by some of the most distinguished naturalists and physiologists of the world. Kaltenbach and Professor Huxley, who have paid considerable attention to their history, bear out Reaumer's assertion of the infinite and almost incredible powers of multiplication possessed ky these feeble looking plant-lice. That author calculates that a single aphis may, in five generations, be the progenitor of nearly six millions of descendants.

These insects can be found on almost every species of fruit trees, etc., especially on the foliage and young growth. Packard names them as follows:

Aphis rosea-Found in the rose.

Aphis mali; Aphis mali filias-Found on the apple.

Aphis cerasi-Found on the cherry.

Aphis persicae-Found on the peach, etc.

Either of the above species can be destroyed by spraying or washing the under side of leaves infested, with either of the sulphur washes recommended in Rule 1, page 11, with this exception: one pound of either soap should be mixed in one and one half or two gallons of water. Spraying or washing with a decoction of tobacco will destroy them.

Woolly aphis, or apple tree aphis, Figuier calls Myzoxyle mali. "This insect is of a dark russet brown color, with the upper part of the abdomen covered with very long white down. This species of aphis, according to M. Blot, can only exist on that tree. Carried 
away and placed on another, it very soon perishes. It does not attack the blossom, the fruit, nor the leaves, but fixes itself on the lower part, of the trunk, whence it propagates itself downwards as far as the roots, underneath the graftings, etc. It also likes to lodge in the cracks of the trunk and large branches; but it generally looks out for a southern, and avoids a northern aspect. It is not active, walks very little, and its dissemination from one place to another can only be explained by the facility with which so small an insect can be transported by the wind, its lightness being still increased by the down which covers it."

"The Myzoxyli mali renders the wood knotty, dry, hard, brittle, and brings on rapidly all the symptoms which characterize old age and decay in trees attacked."

We have visited orchards this season which are terribly infested by this pest.

\section{Remedies Recommended.}

M. Blot, for preserving the apple trees from this pest (woolly aphis), says: "Employ for the seed-beds the pips of bitter apples only; give to the nursery and to the plants only as much shelter as absolutely necessary; avoid those sites which are low and damp; encourage the circulation of air and the desiccation of the soil; surround the foot of each apple tree with a mixture of soot, or of tobacco and fine sand."

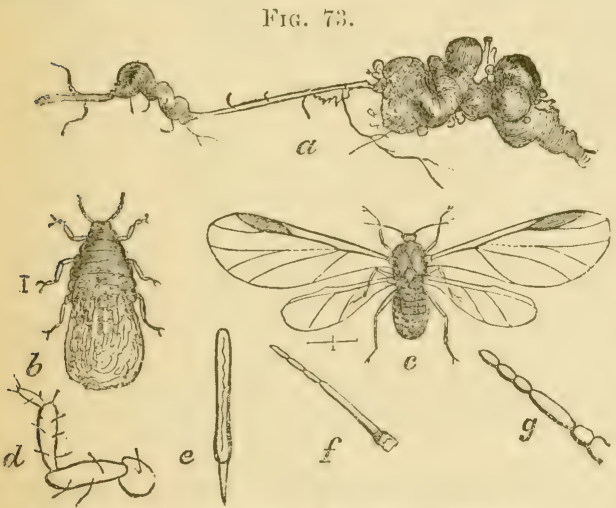

We think if the tree is thorroughly sprayed with a solution of one pound of concentrated lye to one gallon of water, that on repetition of the washing or spraying with either of the sulphur washes recommended in Rule 1, page 11 , this pest can be exterminated, or by applying coal oil mixture. (See article on Mealy Bug, page 40.)

These insects occur sometimes in great abundance, forming in the Fall season

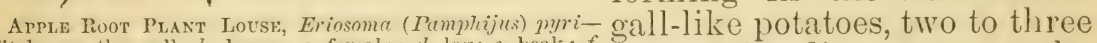
Titch. a, the gall; $b$, larva; $c$, female; $d$, ley; $e$, beal ; $f$, inches in diameter, on the
antenna of female; $g$, of larva.

neath the surface of the ground. roots of apple trees, just be-

Hot water (temperature $150^{\circ}$ ) poured around the roots is said to be a good remedy for the extermination of the apple root-louse. We prefer a solution (B., Page 43) poured around the roots, at a temperature of $130^{\circ}$. 


\section{RETURN FRUIT BOXES.}

The practice of sending fruit to market and returning the boxes and packages for future use furnished an excellent opportunity for the spread of insect pests, especially the codlin moth and scale insects. Many districts at isolated points have been infested by pests from this source, as the pests were not only brought to the orchards in bores or packages used in shipping apples and pears, but also in packages used for shipping peaches, apricots, etc. In the Spring of 1880, the late Reuben Kerchival, of Courtland, Sacramento County, discovered that his peach baskets (ten thousand) were infested by larvæ of codlin moth, from six to thirteen in each basket. He effectually cleansed the baskets and boxes by dipping them into boiling water to which some concentrated lye was added.

At santa Cruz we could not find codlin moth in any orchard visited. At a fruit store we found boxes returned from San Francisco; shipped in November and returned last Spring. The boxes were apparently clean, but some pieces of covers substituted for the ones sent contained pupa cases of codlin moth, from which the perfect moth had emerged a short time previous.

Boxes made of fir lumber should not be used for return purposes. There being but little pitch in the lumber, the larva of the codlin moth bores into the wood and secretes itself, making it difficult to destroy the larva or pupa. At the State Fair last year we exhibited an apple box cover made of fir lumber, taken from a box returned from San Francisco, containing nineteen larvæ of codlin moth, hibernating in holes bored by the larvæ in the wood. They will not bore in pine lumber in which there is pitch. Fruit growers should not receive any boxes (or parts of boxes) or packages in return for their own that belong to any other shipper.

Fruit dealers (peddlers) should be prevented from carrying bores not properly disinfected, from one fruit district or orchard to another.

The cheapest and best method for disinfecting fruit boxes is that recommended in Rule 3, page 11.

At shipping points, such as Sacramento, San José, Stockton, Vacaville, etc., shippers should have such arrangements made that all boxes could be disinfected at a nominal cost.

This day we met a man peddling tomatoes. The nail holes and cracks in the boxes were infested with larvæ and pupæ of codling moth. Good-naturedly, he gave us a box to keep as a specimen.

\section{SCALE INSECTS ON NURSERY STOCK AND FRUIT.}

One source of the spread of insects injurious to fruit and fruit trees, is the transportation of nursery stock from one section of the State to another. The scale insects have been spread in this manner' to a very great extent. For instance: Mr. A. comes to Sacramento with a choice collection of trees, etc., and offers them for sale through some dealer ignorant on the subject of insect pests, and desirous of 
making the stipulated commission as speedily as possible. It is probably known to some persons that there are orchards in MI. A.'s district infested by dangerous insect pests. A.n inquiry is made regarding the insects referred to. The dealer, or Mr. A. if he is present, answers promptly that there are no such insects in the section of the district from which the trees, etc., were shipped. What proof is offered against the supposition that many, or may be all, of the trees, ete., are infested? None whatever; for we have only the word of the dealer, who wishes to make his commission, on the one hand, and the word of Mr. A., who wishes to sell his trees, etc., on the other band, both selfishly interested parties.*

The shipment of fruits to market is another source of the spread of scale insects. Examination will establish the fact that many of the foreign lemons found in our markets and stores are infested witl scale insects. A close examination of the Los Angeles oranges show that many are infested with scale insects. Many of the apples and pears offered for sale in San Francisco and elsewhere are infested with scale insects. These fruits, in the course of trade, are shipped and reshipped from point to point, and are thus spread throughout the whole state. Mr. Ashmead, of Florida, in a recent publication on "Insects Injurious to Fruit," etc., writing of the "method of spreading from tree to tree, and from grove to wrove," says: "In my opinion, there are but three principal ways of transportation: first, on nursery stock; second, by the wind; third, on the fruit itself." We have positive proof that the scale insects have been carried from one orchard to another, and from one section of the State to another, on nursery stock and fruit. WV hope that fruit growers will, for their own protection, assist the Boards of Horticultural Commissioners and local Inspectors in their efforts to protect the horticultural interests of the State, by enforcing the laws for the protection of horticulture and viticulture. When we calculate the immense loss-amounting already to millions of dollars-which the scale insects have cost the counties of Santa Clara and Los Angeles, and the codlin moth and red spider the central counties of the State, during the past four years; and above all when we reflect that, unless strict rules of prevention are adhered to, every fruit-growing district in the State will be infested within a few years, we feel that immediate, united, and strenuous efforts should be made to arrest the sinward march of these destructive pests. "It may be, and doubtless is true, that, as the State becomes more thickly settled, successful culture will be confined to the intelligent and well informen; yet the fact nevertheless remains, that there are many fruit growers who will do nothing to ward off the evil until they are forced to measures by dire necessity." "They take no notice of the few so-called bugs that make their appearance in the orchards, because they do them no material injury; but when these so-called bugs have increased to such all extent as to make it a question of "fruit or no fruit with them, their energies will be suddenly aroused, and the exponditure of dollars will be required to accomplish that which as many cents would have sufficed to do at the beginning." * Unfortunately for fruit growers, this comparison is founded on facts which occur every
planting season, not only in Sacramento, but in every fruit-growing district in this State. 


\section{QUARANTINE.}

It shall be the duty of local Inspectors appointed by Chieft he Executive Horticultural and Health Officer, to strictly enforce such quarantine rules and regulations as approved by the State Board of Viticultural Commissioners for the protection of fruit and fruit trees. By these means, fruits, plants, scions, etc., can be seized, as prescribed in sections three and four of an Act entitled "An Act to define and enlarge the duties and powers of the Board of State Viticultural Commissioners, and to authorize the appointment of certain officers, and to protect the interests of horticulture and viticulture."

This will be the important part of the work, and will be supported by every enterprising fruit grower in the State. Only by vigilance can the spread of insect pests be prevented, especially from infested orchards, or districts of counties whose executive authority refuses to comply with the law, by refusing to appoint a County Board of Horticultural Commissioners when a proper petition is presented, as required by statute.

In order that the enterprising fruit growers of California may perfectly understand what they have to protect themselves against, we call their attention to the following:

We visited a county recently in which a large majority of the orchards are infested with certain insects, known to be injurious to fruit and fruit trees. We were present at a meeting of the Board of Supervisors of the county then in session. A petition was presented with nearly twenty signatures attached, asking the Board to appoint a Board of Horticultural Commissioners for the county.

The Board of Supervisors is composed of five members, two of whom are fruit growers. Both fruit growers advocated granting the request of petitioners; first, as a public necessity; second, in compliance with their duty as public servants sworn to obey the laws, stating that the District Attorney of the county gave his opinion that the law was mandatory. Two members opposed granting the request of petitioners.

Number One presented the names of three persons who were opposed to the appointment of a County Board of Horticultural Commissioners. 'Two of them he intimated were threatened by financial difficulties, and if compelled to clean their trees, the mortgagee holding a claim on the property, would be likely to get the property. And only by mandamus would he vote for granting petition.

This argument was answered by one of the petitioners (an extensive fruit grower), as follows: If the orchards referred to were not cleaned so that they would be restored to their former value, or that they would produce marketable fruit, the mortgagee would be sure to get the property.

Number Two opposed grating the request of petitioners, and made some reference about moths in his store. It was suggested that other counties might quarantine themselves against infested fruits and 
trees from that county, and thereby be detrimental to the county at large, should they fail to appoint a Commission as petitioned for. Number One asked the gentleman with the moths in his store (the question was probably suggested by reference to quarantine): Suppose a man buys a pair of pants in your store, and afterwards he discovers they are moth eaten, what redress has he?

Number 'Two-That was his (the buyer's) own look-out.

Question taken-Ayes, 2; noes, 3.

Be it remembered that the county referred to, is probably the largest fruit producing county, and the orchards more generally infested by scale insects than any other county in the State, and its shipment of trees go to nearly every county in the State. Therefore the necessity of protection against importations from infested orchards and nurseries in other counties.

\section{EXPERIMENTS.}

"It is common for us, in reporting experiments, to think we have facts, that are the outgrowth of our fancy only, and have no support in nature." "It is well worth the care of any one who should wish to be sure, as every one should, of conferring a benefit upon his fellows, rather than risk doing them an injury, to delay the expression of results of experiments until the correctness of their results are tested by repeated trials."

"Before advising your neighbor to adopt a certain course or remedy, be sure, by repeated investigation, you are possessed of a fact, not a fancy. Experiments, to be convincing, require that they be subjected to well-defined, clearly perceived conditions."

In reporting results of experiments it should be remembered that, "It is the weakest link that determines the strength of the chain."

In reference to the various solutions, etc., recommended as insecticides, and applicable for use on fruit trees, we respectfully call the attention of the reader to "Structure, Chemical Elements and Growth of Trees." (Page 64; also to Fig. 75, p. 66.) The structure of the treepith, heart-wood, sap-wood, cambium or growing layer, inner bark, green layer of cellular tissue, the outer or corky layer bark, and the pith rays of hard cellular tissue, connecting the pith with the green or middle layer of bark, are fully described.

It will be readily understood how easily a tree or plant may be injured. From personal observation we know that serious damage has been done to trees by the use of solutions, etc., applied as insecticides, that contained matter detrimental to the tree if used improperly, and its recommendation as an insecticide based on experiments not properly tested. For instance, Mr. A. was told by Mr. B. to use a certain solution as an insecticide on his trees; he, Mr. B., had tried it as an experiment, and found in a few days, after washing, that every particle of insect life on the trees washed was destroyed. Mr. 
A. did his work as recommended by Mr. B., and also informed his neighbor, Mr. C., of the discorery, etc. For some time the new discovery was heralded as a success everywhere in the neighborhood. At the end of six months another discovery was made, the solution or wash applied contained some substance detrimental to the trees, which it took time to properly test, and a serious loss followed. When an examination was made, it was found that the green layer of cellular tissue, the inner bark, and the cambium or growing layer, of every plant washed, was destroyed. Result: The discovery of Mr. B. was a success as an insecticide, but unfortunately it was pernicious to plant life.

Fruit growers, beware of acids and mineral oils as insecticides. If either are used it should be in a diluted form.

\section{WHAT HORTICULTURISTS SHOULD LEARN.}

Horticulturists should make the study of insects, especially those known to be injurious to fruit and fruit trees, a part of their every day work. It is as necessary for them to understand the natural history and habits of such pests of the orchard as it is to understand how to plant, prune, etc.

Some fruit growers think that for such practical investigation of insect life a scientific knowledge of the anatomy and physiology of these creatures is indispensable. Such is not the case. It requires some apparatus, which can be procured at a nominal expense, a llttle patience, and an interest in the subject investigated, to learn eractically what they have depended on others to furnish.

The apparatus required: One small microscope, say $\$ 10$; one onenich focus watehmaker's glass, $\$ 1$ 50; glass mountings and balsam, $\$ 150$. However, investigations may be made by use of the one-inch pins, costing $\$ 150$.

The investigator should procure some of the prominent publications on insect life, such as: "Insects Injurious to," etc., Harris; "Inseet World," Figuier; "Half Hour With the Insects," Packard; "Guide to the Study of Insects," Packard. These publications will be found of great assistance as a guide to reach definite results, especially the Guide of Packard.

Should the fruit grower be unable to give half an hour of his time each day for such investigations, the ladies and children of the household should be trained to make observations that, when compared with those of others, such information will be obtained as will repay them for their time and labor.

When the life, history, and habits of these insects is learned to such an extent as to be familiar with the metamorphoses (changes), as larva, pupa (chrysalid), Imago (perfect insect), the fruit grower can go to work intelligently to exterminate them.

By following the above recommendations the result gained will be replacing theoretical by practical information. 


\section{REPORT OF MESSRS. CHAPIN AND VESTAL.}

LWe have just received a copy of a report made to the Santa Clara Valley Horticultural Society, August 6, 1881, by Dr. S. F. Chapin and D. C. Vestal, members of the County Board of Horticultural Commissioners of Santa Clara. Want of space prevents the publication of this excellent report in full. We considex this the most valuable report yet published of the natural history, ete., of the scale insect Aspidiotus perniciosus, Comstock. The manner in which the results of the experiments made and the remedies discovered are reported, reflects great credit on the gentlemen named.]

We have now specially to deal with a new species of Aspictiotus, which, so far as known, cannot be found elsewhere, although Mr. IV. B. West now reports its presence at Stockton, and Chief Horticultural Officer Cooke states that it has invaded the ricinity of Sacramento, no doubt having spread from this locality. Its ravages have caused widespread alarm, and it is not too much to say, that unless it is speedily destroyed, it will utterly ruin the fruit interests of this coast. It does not simply check the growth of the tree, but it covers the tree literally entire, and the fruit nearly as much so, rendering it musalable and unfit for use; and, if left unchecked, the tree is killed in three years' time. The trees attacked embrace all varieties, excepting the apricot. The Black Tartarian cherry and the Glout Morceau pear are free from its presence, and the Beurre Hardy pear nearly so, and the Gross prune and quince. It can be found at home upon the currant. Poplar and other ornamental shade trees give it a support. Osage orange hedges are badly infested. 'The effect of the scale insect upon the tree is peculiar. After a short residence there, the green layer of the bark becomes stained a very dark red color, which continues until the death of the limb or tree, unless the insect be killed. The bark may then be restored to its normal color' and health. The damage in this county has already become so great as to cause the most serious losses, not alone to the fruit growers, but also to the public at large, and from the orchards affected, has greatly lessened the revenue which has been derived from the production? and sale of fruit. One instance stated definitely will suffice to show these losses. This orchardist states that he has two thousand trees badly infested with scale. One thousand of these trees are totally destroyed, and will be dug up this season; the balance are badly injured, but can probably be saved. This portion of his orchard, in health, returned at least five thousand dollars per year. His loss on crop from these last year was over two thousand dollars. There is a total loss of crop this year on fifteen hundred trees. This orchard has regularly paid an interest of ten per cent. on one thousand dollars per' acre. The scale pest alone has caused a loss of twenty thousand dollars to this orchardist.

The Assessor's roll for 1881, reports in this county two hundred and thirty-five thousand five hundred and thirty-seven bearing trees of the apple, pear, plum, and peach. This does not include the large number: of trees which have been destroyed and are unfruitful, 
neither the immense number of young trees that have been planted, but not yet paying, and as observed, it leaves out the large number of other varieties, cherries, almonds, apricots, etc., in bearing, which it is estimated would make a grand total of nearly one million trees. Should the losses experienced by the orchardists now suffering, be carried out to all, you can readily estimate the astonishing result. The value of the county fruit crop for 1880 , is returned at nine hundred and seventy-six thousand four hundred and seventy-five dollars, notwithstanding the immense losses incurred. Thus the magnitude of this evil becomes apparent, and the problem to be solved is of vast importance. This pest is locally known as the Small, Round, Black Scale.

The scale insect is massed upon the bark of the tree and fruit as well; the scale of a dark gray or blackish and tough material, which covers the insect, being very small and round in shape over the female, while that covering the male is much smaller, and elongated on one side. In both, the higher and central portion of the scale has a yellowish color, and directly under which may be found the insect itself, which is soft and delicate in structure, and of a pale straw color. There is no connection between the cover and the insect, which is merely protected by it from harm. The shell-like scale is formed either by the cast off skins of the larva, or by a waxy secretion of the body of the insect.

The young female insect is oval in shape, and flattened. It emerges from the mother scale by the viviparous process, and not by hatching from an egg, as the species Aspidiotus conchiformis. At first it is rery small, and hardly perceptible to the naked eye, but careful observation will detect it as a minute yellow dot on the bark of the tree, crawling about with the six legs with which it is provided, and seeking a favorable locality upon which to fix itself for life. It will crawl about for only a day or two, and then fastens itself to the bark by a beak-like protuberance which it inserts, and procures nourisliment from the juices of the tree. Immediately upon fixing itself it begins to be covered with a silvery material, which, as it grows older, is gradually changed in color to a very dark hue, and enlarges to the size of about one sixteenth of an inch in diameter. The insect, soon after fixing itself, loses its legs and antemmæ, and thus remains through life, keeping its flattened shape, but growing wrinkled and almost round, gradually increasing in size to perhaps one sixty-fourth of an inch in width and one fiftieth of an inch in length when full of young. After the young emerge it is dried up and disappears. We have counted from the female, when full of young, between fifty and sixty of the minute sacs, which answer for eggs, and in which are dereloped the young, perfectly formed insects, ready to crawl about.

The young male insect is produced in the same manner and at the same time, though not in such numbers; perhaps a half dozen males to a hundred females. In size the male is about one third that of the female and in shape very different, being elongated and more angular, provided with six legs, placed differently upon the body, with two antenne and two eyes, and with a rounded teat-like protuberance at the rear portion of the body, ending with a point. At this stage of its existence the male has no wings, and it cannot be discerned without the aid of a magnifying glass. The color of the 
young male is not a yellow, but of a steel-like or whitish hue. It crawls about and fixes itself upon the bark, as does the young female, and becomes covered with a scale in the same manner, but which is elongated upon one side, and not more than one half the size of the scale of the female. The male, after remaining its allotted time in the pupa state, emerges as a fully developed insect, having eyes, antennæ, six legs, and one pair of very long wings of a reddish and transparent appearance; the protuberance at the rear end of the body is developed into a very long tapering point, nearly as long as the body itself. The perfect winged male is so minute, it can with great difficulty be discerned by the naked eye crawling and flying about in search of the female, which it impregnates under the scale; and then, having fulfilled its mission, dies. This season we saw the winged males first appear on March 23d, and in great numbers for a few days. The first brood of young scales appeared the latter part of April. On June 27th we found the males from the first brood under the scales nearly developed, with appendages and wing pads, and on July 2d large numbers of them flying about; also as late as July 25 th and still later on, August 2d, a few were seen. On July 23d the trees were covered with the young of the second brood. August $2 \mathrm{~d}$ young males of the second brood were found crawling about. Bark scraped clean on the twenty-third of July was found on the twenty-fifth alive with young insects, and some of them already commencing to be covered with scale.

The winged males may be expected again to appear the latter part of September or the first of October, and the third brood of young the latter part of October and in November. The last brood remains through the winter under the scale until the approach of warm weather in the Spring when they again appear. While the Aspidiotus conchiformis will develop but one, or at most two broods per season, this species, Aspidiotus perniciosus, will produce three broods, and each female probably fifty young. The natural enemies of the scale insect are the larve of some varieties of the coccincella, or ladybirds. This season has developed, in great numbers, the presence of another important enemy of the scale, viz.: the Chrysopa, or lacewinged fly, the larve of which prey upon it. This is a beautiful. slender, and delicate fly, bright green in color, with large, golden eyes, and very long wings, like lace. The eggs are very minute, white, and oval in shape, and are attached by a long and slender pedicle to the under side of leaves or the fruit. The larva is about one quarter of an inch long-slender and tapering from the middle toward both ends. It is provided with jaws, each perforated with a hole through which it sucks the juice of its victim.

[The result of twenty-six experiments here reported, from which we select Nos. 5 to $11,15,16,21$, and 22.]

No. 5.-Concentrated lye, one pound; water, one gallon. February, 1881. - One almond tree, one Easter Beurre pear tree, and two aply) trees, grafted, were washed by brush with this strength of lye in order to destroy the red spider and its eggs, which could not be destroyed by previous applications of lye, one pound to five gallons and also one pound to three gallons. Another and the main reason being to ascertain the effects of very strong lye upon the trees. No scale upon these trees. Result-destroyed the red spider eggs com- 
pletely, drying them up at once and not one so far as known up to this iate (August 6,1851 ) having hatched since the application was made. The cffect upon the bark and health of all these trees was wonderfully good; the bark being very smooth, and having a bright green velvety aiplearance and totally free from all moss or other parasites.

No. 6-Concentrated lye, one pound; water, one gallon. The experiments in this number were made upon a section of orchard in a square block comprising three hundred and fifty-seren Ickworth plum trees cut down and grafted into Petite prune; some yearling prune trees having been put in in places, and washed as were the plums. Of these, one hundred and twenty-six trees were washed in February 1881, with the above strong lye applied with a brush. Among the three hundred and fifty-seven trees were eight trees badly infested with scale. No others had any scale upon them. The infested trees were scattered about as follows and washed as indicated. Number ten in first row and four in eleventh row were washed with lye one yound to three gallons water; effect was not quite sufficient to completely destroy the scale, though so injured that they did not breed. Afterwards these two trees were washed one pound to one gallon, and this effectually ended the scale. Numbers seven in sixth row, ten in seventh row, eleven in twelfth row, eight in fourteenth row, three in seventeenth row, and eleven in seventeenth row were washed with lye one pound to one gallon water with the effect of completely destroying every scale, and at this date not a vestige of scale can be found. The trees have been in the finest possible condition from the time of this application.

No. 7.-Five Bartlett pear trees obtained and planted last Winter and scattered among a considerable number, although carefully examired at the time for scale, were found in June to have a few scales upon them. These were at once treated with one pound to one and one half gallons of water, which immediately destroyed all the scale. But applied at this season of the year it takes more effect upon the bark, and is better used in the Winter.

In the following experiments the trees were all badly infested with the scale.

No. S.-Concentrated lye, one and one half pounds; water, one gallon. June 24, 1881: applied to two Clairgeau pear trees; brush used in order to save foliage; many limbs in appearance dead from effects of seale. June 27: trees burned considerably; scale killerl. July 2: much of the bark showing a healthier appearance. July 23 : trees still better. August 2: no sign of scale; green layer of bark being restored rery rapidly; the fruit quite clean because no scales of second brood were upon it.

No. 9.-Concentrated lye, one and one half pounds; water, one gallon. July 23, 1881: applied on a portion of tree to ascertain the effect upon the stain of the bark. July 23: the bark where washed shows much less stain; lighter in color and the green layer being restored. August 2: stain rapidly disappearing.

No. 10.-Concentrated lye, one pound; water, one gallon. July 5 , 1851: mixed accurately, and applied same day upon pear tree. July 23: scale entirely destroyed; bark slightly burned by the wash, but now appears perfectly healthy and good where previously sound; leaf buds healthy. August 2 : no signs of seale; constant improve- 
ment in tree. Considered the best wash for Winter use while the trec. is dormant.

No. 11.-Concentrated lye, one pound; water, one and one half gallons: tree washed same time as above, and with the same good results-scale killed.

No. 15.-Kerosene, low grade and heavy. June 1, 1881: applied to two pear trees; syringe with coarse spray used and thrown all over trees. June 27: observed that foliage had been killed, and the trees considerably affected-scale killed. July 2 : new leaf buds coming out. July 23: new foliage all over trees, and new vigor all through trees; new shoots six inches long-scale all killed and green layer of bark, fresh and healthy to all appearance. August 2: foliage increasing rapidly all over the trees and the trees gaining in health.

No. 16.-Kerosene, high grade. June 1, 1881: applied by spray upon two pear trees. June 27: observed that the foliage had not been killed, but that the scale had been all destroyed, the trees apparently uninjured. July 2: new leaf buds coming forth. August 2: trees healthy; foliage uninjured; scale showing no signs of its presence, the fruit showing less effects from scale on account of the wash it had received.

No. 21. - Vhale oil soap and sulphur mixture (codlin moth wash), one pound; water, one gallon: June 23, 1881: applied by spray over pear tree, covering foliage and fruit thoroughly. July 23: scale killed; trees gaining in health; green layer of bark being restored; fruit greatly improved in appearance. August 2: tree still improving, also the fruit.

(This wash is recommended to be applied from May 15 th to June 15th. This wash, of one half the strength here used, has proven ineffectual in destroying the scale, and should, in all instances, be used in the strength of one pound to one gallon of water.)

No. 22.-Soft soap, one pound; sulphur, 1 pound; tobacco, one pound; water, three gallons. July 5, 1881: applied upon two trees by spray, covering trees, foliage, and fruit thoroughly. July 23, 1881 : quite effectual; scale mostly destroyed, but not altogether; trees and foliage not affected by wash; fruit greatly improved in appearance. August 2, 1881: same as noted above.

(A very good wash for Summer use; should be applied from the middle of May to the middle of June.)

A Fellenberg prune tree in another orchard, washed with the same preparation June 1, 18s1, and badly infested with scale, shows, at this date, (Aug. 6th), that the scale has all been destroyed, and the tree in a thrifty condition.

Thorough and constant cultivation of an orchard should be kept up, and diligent watchfulness of every tree by the owner himselt exercised, so that no scale insect shall escape observation, and when found, the proper remedy should be instantly applied. The above experiments, Nos. 5, 6, and 7, answer the frequent inquiries as to how a young orchard may be kept free from the scale insect. In the orchard referred to, the scale pest has been stamped out at its inception. Our investigations show that where crude petroleum has been used it kills the tree, if the sap is moving; where the tree is entirely dormant, it may be used, perhaps, without destroying the tree. Crude petroleum is too heavy, and its use is not recommended. 
Kerosene (refined coal oil) in no instance has killed the tree, but has destroyed the scale and relieved the tree from its presence, thus enabling it to recover. While not fertilizing the tree, it is effectual as a remedy, and can be applied at any season of the year, if of a high grade (150 test). The best time, however, to apply it, is when the tree is dormant, and invariably used when the tree is dry, as it will be of no avail if applied to a wet surface. It should be applicd in as fine a spray as possible, and as little used as will once cover the tree, taking care that the entire tree is sprayed; in this way high grade kerosene is recommended. A lower grade (110 test) may be used only when the tree is dormant. The best time for application is in the Autumn, after the leaves have fallen. Concentrated lye has proved itself, where used of sufficient strength, to be thoroughly reliable and effectual, and has the great property of fertilizing the tree and soil, as potash is one of the natural constituents of both, and is required for the health of the tree. Its use is therefore recommended-sixty pounds of the concentrated lye of the American Lye Company, is equivalent to one hundred pounds of Commercial potash.

All orchards, even though showing no scale, should be washed with concentrated lye of the strength of one pound to three gallons of water, as this strength will keep trees healthy, and free from moss and filth. Where infested with scale insects, the strength of one pound of lye to one gallon of water (or not less than one pound to one and one half gallons of water) should be used. 'This strength will destroy all scale, and also will completely destroy eggs and larvæ of the red spider, as found from experiments made; any less strength will not destroy the eggs of this mite. Lye should be applied in a spray, by the use of a garden syringe, or, where large orchards are treated, the most economical means is to use a large barrel or tank placed upon a wagon or sled, and drawn through the orchard, and the solution thrown upon the tree by a force pump, through thirty or forty feet of hose, to which is attached a nozzle, having for its opening a simple straight slit, very narrow in width, and one sixteenth to one eighth of an inch long. Great care should be observed to cover all portions of the tree, as upon its thorough application depends its success. Care should also be taken to protect the body from its effects, as it burns the skin. The lye is best broken up and dissolved in a small quantity of boiling water, and then the required strength obtained by adding cold water. Strong lye should only be used when the tree is dormant, as in any effectual strength it will burn the foliage. One hundred large trees per day can be washed thoroughly.

Where trees are very bad it is recommended to first apply kerosene in the Autumn, and then by the time the sap starts late in Winter apply lye, one pound to two and one half gallons of water. For Summer washes, (other than high grade kerosene) to be best applied about the first of June, the washes, No. 21.- Whale oil soap, and sulphur. Mixture, one pound to one gallon of water; or, No. 22.Soft soap, one pound; sulphur, one pound; tobacco, one pound; added to three gallons of water, are all that can be recommended.

The different proposed means of destroying the scale, by boring the trunk of the tree and putting in the hole preparations of various 
sorts, have been proven ineffectual, as we have observed that where tried no effect at all has been produced, and the trees are still alive with scale. So far as we can determine, no remedy can be effectual which does not directly reach the scale, and through its penetrating power, destroy the insect itself. The above experiments show that young orchards may be kept free from scale by constant care, and where invaded, the insect at once destroyed. Old orchards, infested very seriously, may become cleared and the trees given new life and vigor. It is the firm conviction of your committee that, could united action be secured, this pest could be speedily destroyed and stamped out of existence. 


\section{STRUCTURE, CHEMICAL ELEMENTS AND GROWTH OF TREES.}

[Extracts from a paper read by Col. W. S. Clark, President M[assachusetts Agricultural College.]

"The young willow, under kindly influences, will increase in size and weight daily until the chilling winds of Autumn breathe upon it. Then the leaves fall, growth ceases, and the plant enters upon a period of repose, similar in many respects to the hibernation of animals. This annual cessation of the vital action in plants appears to be essential to the health of most species, though a few, like the orange and lemon, do not require it. In cold climates, the absence of lieat in Winter, and in warm latitudes, the want of water during the periodical dry season, are the principal causes which operate upon vegetation to enforce this law of nature."

"The distinction between deciduous and evergreen species is, that the former lose their foliage at the end of the growing season, while the latter retain each perfected leaf one, two, or more years. Nevertheless, evergreens usually have their time of rest no less than deciduous plants, and those which are deciduous in one climate, may become evergreens in another. Thus the apple and plum tree have become evergreens in Madeira."

"Professor Hoffman made a series of experiments from 1563 to 1870 , to determine whether this annular period of rest was really necessary for ordinary plants. He found that when the lilac and other similar species were forced under glass to grow continuously by the constant pressure of heat, light, moisture, and proper soil, ther ceased to bloom after the first year, and died on the second or third. Hence the importance, so well known to skillful gardeners, of giving alternations of heat and cold, moisture and drouth, to plants cultirated under glass, during their proper seasons of activity and repose. Persons ignorant of these facts, water them alike at all seasons of the year. The plants having no opportunity to ripen their tissues, can never be in a condition to blossom" (or bear fruit).

"After the fall of the leaves, and the ripening of the wood and buds, the stem and branches of most trees and shrubs will be found, upon examination, to be unusually dry and free from sap, and it has been said that this was an indication of hardiness. That most of our indigenous species assume this condition during about one half of the year is doubtless true, but the presence or absence of sap cannot be considered as conclusive evidence of tenderness or hardiness. The grapevine appears quite porous and free from sap in December, but is often winter killed. On the other hand the sugar and silver-leared maples are usually full of sap on some days of every month in the year, and yet are perfectly hardy."

"Thlien ordinary cells are united into a more or less extended structure, they constitute what is known as cellular tissue. This may be soft and pulpy, as is in the flesh of an apple, loose and tender as in the pith of an elder, firm and tough as in birch-bark, 
or hard and brittle as in the shell of a hickory nut, or the stone of a peach."

"The tissue of the inner bark, consisting of very long and narrow colls orerlapping cach other at the ends, is called bast; and that of the stem, in which the cells are similar, but shorter, is called woody fiber. The tubes which are formed, are styled ducts or vessels, and, as they are mingled with woody fiber in the annual growth of timber, the ordinary combination of these is named fibro-vascular tissue."

"When these elongated cells and clucts are straight and parallel. as in the chestnut, the wood of which they are the warp splits casily, but when they are interlaced and blended irregularly, the longitudinal grain of the wood will resemble that of elm."

"Every seed and every young plant consists wholly of cellular" tissue, but with the development of leaves is combined the growth of fibro-vascular tissue."

"The first vessels to appear in the plantlet are arranged in a circle around a column of tissue, which remains loose and solt, and after the first season dries up and dics. This is called the pith, and seems essential to the life of every woody stem and branch during its infancy, although its special function is unknown. Between the vessels around the pith may be seen the rays of cellular tissue, which ultimately become hard and firm, and which unite in bonds, never broken except by some external force, the inside of the stem with the inside of the bark. These rays make up the woof and have much to do with the distinctive peculiarities of different sorts of timber."

"Immediately outside the vessels inclosing the pith grows a layer" of woody fiber, upon which, in a more or less developed state, according to season, is a layer of organizable material, called cambium, which may be regarded as the seat of life of the plant. Next to the cambium, and united to the wood by the rays from the pith, is the bark, consisting of three layers."

"The inner, or fibrous layer, is formed by bast cells, and firm cellular tissue. Surrounding the inner bark is a layer of cellular tissue. in which the rays from the pith terminate, and which is named the wreen layer, because it often exhibits this color in young shoots, and then performs the same function with the green tissues of the leaf. Outside of all this is the corky layer, consisting of dry, dead cellular tissue, and developed amnually from the green layer. This is not usually of much thickness, or consequence, but sometimes, as in the cork aak of Spain, it becomes an important article of commerce."

"The growth of our trees goes on in the cambium layer, from which is produced annually a layer of wood, and a layer of bark, each formed of longitudinal fibro-vascular tissue, and horizontal cellular tissue."

"As the trunk expands, the outer bark cracks and falls off, as in the shag-bark hickory, or distends and envelops it with a somewhat smooth cuvering, as in the beech and birch. In these latter cases the annual cortical layers are quite thin, and the outer layer very gradually wastes away, under the influence of winds and storms. In the cork oak the outer layer is specially thickened, and if removed every eighth year, may be obtained in stout, elastic sheets, which woulil crack and fall to the ground in the process of time, if not harvested. 
The structure of the root is not unlike that of the stem, ercept that the pith is usually wanting, as well as the green layer of the bark, which could not be formed, nor be of any use in the dark earth where the root makes its home."

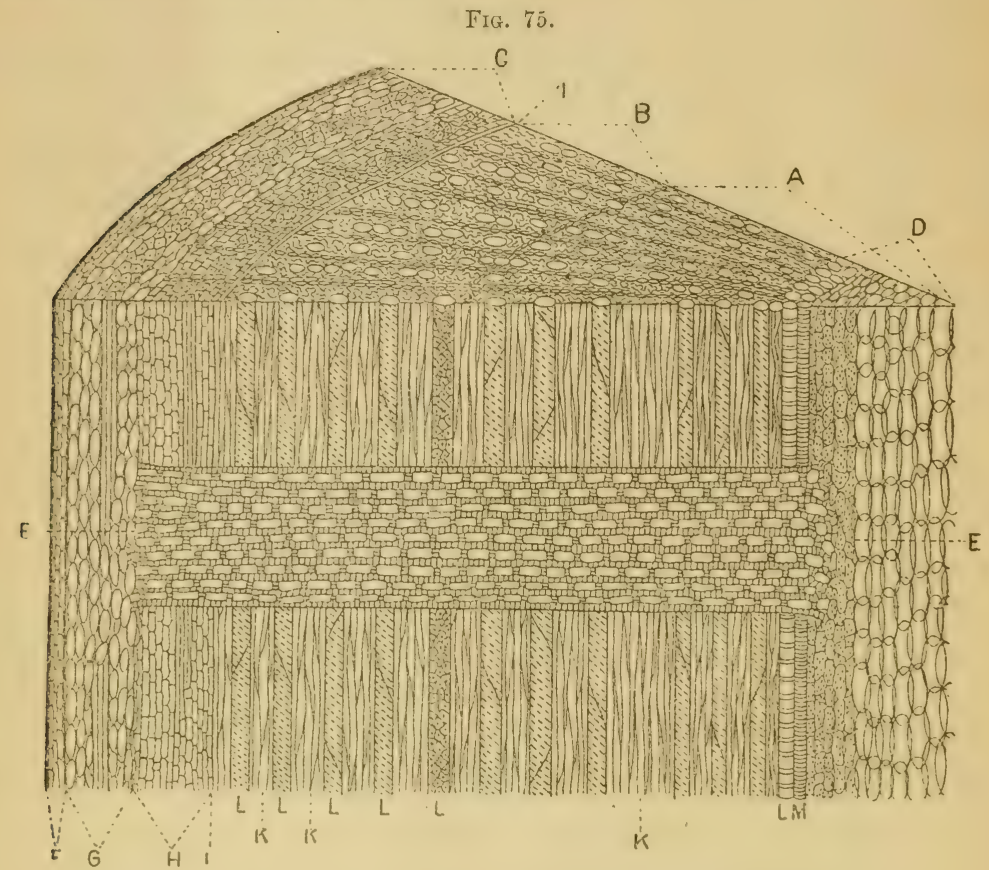

Description of Fig. 75 .

Fig. 75 represents a section, both vertical and horizontal, of a branch of a sugar maple, two years old, as it appears in December. The portion included in the lines marked $\mathrm{A}$ is of the first year's growth; those marked B indicate the wood of the second year; while those marked $\mathrm{C}$ inclose the three layers of the bark. D represents the pith of loose cellular tissue; E the pith rays or silver grain of hard cellular tissue connecting the pith with the green or middle layer of bark, which also consists wholly of cellular tissue; F marks the outer or corky layer of the bark, which is composed of dry, dead cells, which are formed of consecutive layers from the outer portion of the living green layer; $G$ is the green layer of cellular tissue. H shows the liber or inner bark, made up of cellular tissue penetrated by long bast cells, arranged parallel with the axis of growth. I represents the place of the cambium or growing layer of organizable material which descends from the leaves between the liber and the sap-wood during the period of growth. I is woody fibre which gives strength to the stem, and through which the crude sap rises. L indicates the vessels or ducts, with various markings, such as dots, rings, and spirals, which are formed most abundantly in the Spring, and usually contain no fluid. They convey gases and aqueous vapors, and it may be that a large proportion of all the water ascending from the roots to the leaves passes through them as vapor. $M$ is the layer of spiral vessels or ducts which always inclose the pith, and in the young shoot extend into the leaves and unite them to the pith during its life, which ceases with the first season.

"This part of the plant develops an amuual layer of wood and bark, with rays of cellular tissue like the stem. The number and extent of root branches in the soil, depend much upon its fertility and adaptation to the plant."

"As the vigor of vegetable growth depends chiefly on the action of the roots, the importance of thorough tillage is apparent." 
"The striking peculiarity in the structure of the root is the absorbent power of the young rootless, which are either covered with a thick, spongy layer of cellular tissue, or furnished, as is commonly the case, with exceeding minute but innumerable hairs, which penetrate the crevices of the earth in every direction in search of food. The extreme tips of the rootlets, about one sixth of an inch in length, are not clothed with hairs, nor capable of absorption, but serve as entering wedges for the advancing root, which lengthens only near the extremity."

"The bark of the larger roots becomes thick and impervious, like that of the trunk and its older branches, and the inner portion of the wood, both above and below ground, gradually solidifies, and becomes unfitted for the free transmission of fluids. 'It is then called heartwood, in distinction from the sapwood, through which fluids are transmitted freely. The farther any layer of wood or bark is removed from the living cambium, the less vitality does it retain, and consequently the less useful is it in the economy of the plant."

"The leaf has been said, with some propriety, to be an extension of the bark, and consists of a framework of fibro-vascular tissue forming the stalk and veins, with a double layer of loose cellular tissue covered with a distinct epidermis or skin. The vessels in the leaf stalk and the veins, which are its branches, are also in two layers, the upper commecting the leaf with the vessels surrounding the pith, which are called spiral on account of their peculiar markings, and the lower which are united to the cambium layer through the tissue of the inner bark."

"The distinctive features of the leaf is the presence of stomata or breathing pores, which are usually more numerous on the under sicle. These stomata are furnished with openings, so constructed as to close in very dry air, and open in that which is moist, but they they always remain shut except under the stimulus of light. As the chief function of the rootlets is to absorb the liquid food of the plant from the earth, so it is the special work of the stomata to transpire the surplus water of the crude sap, which has been employed as a carrier of food from one extremity of the countless series of cells which build up the plant, to the other, in some cases a distance of five hundred feet, through imperforate membranes, and against the force of gravitation."

"In regard to the size of vegetable cells, it is difficult to obtain a correct conception, unless one is familiar with the use of a compound microscope. In every cubic inch of maple-wood there are probably not less than one hundred million cells of the venous tissues. The average diameter of ordinary plant-cells is less than one four-hundredth of an inch. And even the ducts or continous tubes are not usually much larger, and are often smaller than this. Professor Gray informs us that sap must pass through two thousand partitions in every inch of bass-wood through which it rises."

"Plants produce all the food and all the vital air which are indispensable to animals. Every growing plant may be regarded as a machine for converting mineral water into cellulose, gum, starch, sugar, and the various albuminoids by the digestion and assimilation of which animals live and grow. Every thriving plant is also exhaling continually under the stimulus of sunlight from its myriads 
of stomata, pure vapor of water and oxygen gas; and we have often wished that once at least in every Summer, these inestimable blessings might become visible as they rise in beautiful though unseen forms and mingle with our atmosphere."

"The chemical elements of plants and animals are of course identical. Three are very common in all organic tissues-carbon, oxygen, and hydrogen-and three more are found wherever there is life, though usually in very small quantity-nitrogen, phosphorus, and sulphur. Besides these there are a few metals which are essential to the growth of healthy and perfect plants. Thus iron in rery minute proportions is found in the green coloring matter, or chlorophyl of every plant; and chlorophyl may be regarded as analogous to the gastric juice of animals, since without it plants are incapable of digesting carbonic acid, or elaborating cambium, or other organizable matter. Potassa, lime, and magnesia, are also necessary ingredients in the food of all plants; and though they are scarcely to be regarded as constituent parts of any vegetable tissue or product, they are absorbed by the roots, circulate in the sap, and are probably deposited in all cells, since a greater or less quantity of incombustible ash remains wherever they are burned. Their presence doubtless aids in the formation of regetable acids and other compounds, and assists in the transference of elaborated or assimilable material, from one part of the plant to another."

"It is a fact worthy of special notice that the amount and kind of mineral matters absorbed by a growing plant may be caused to rary greatly by artificial treatment. The ash of the wild beet contains more soda than potassa, but the best and sweetest sugar beets now contain at least three times as much potassa as soda. As a sola plant, therefore, it was worthless, having scarcely a trace of sugar, but the physiological changes produced by artificial treatment have made it one of the most valuable of agricultural plants, yielding a juice with from twelve to fiiteen per cent. of cane sugar. There is every reason to believe that the flavor of fruits and the most desirable qualities of all the vegetable products of the farm and the garden may be thus improved and controlled by the intelligent use of tertilizers. And this consideration adds practical importance to the study of vegetable physiology. We all know that whenerer a hive of bees find themselves without a queen, or royal eggs, they at once proceed to develop a common egg into a royal larva, by feeding it with a peculiar food. Is it unreasonable to hope that we may learn how to modify as radically the nature and qualities of plants by a similar process?

"The food of plants consists chiefly of carbonic acid gas, and is absorbed from the air by the green parts, which, like the leares and young bark, contains chlorophyl, and are furnished with stomata. More than half the weight of ordinary dry vegetable matter is thus deriver from the atmosphere. Water is the most important of the remaining constituents of plant-food, and in the liquid form is wholly absorbed by the rootlets, though aqueous vapor must, under some circumstances, be imbibed by other vegetabie organs. The elements of water, hydrogen and oxygen, are united with carbon in the same proportion in which they exist in this fluid in the living cells, principally of the leaf, to form the common material of vegetable tissues 
called cellulose, and several other substances having nearly or precisely the same composition, but different properties and uses. These are mainly starch, gum, and several varieties of sugar, which, by the vital action of plants, are transformed, one into the other, or into cellulose, according to the requirements of the vegetable economy. Only a small portion, howerer, of the water taken up by the roots is assimilated, much the largest being exhaled by the leaves. It performs. neverthcless, most valuable service as a common carrier throughout the various parts of the plants, both of those nitrogeneous and other substances absorbed in very dilute solution from the soil, and of these organic compounds formed within the plant and essential to its growth in the several stages of its development.

"The vital fluid corresponding to the blood of animals, and existing in every young and growing vegetable cell, is called protoplasm, and is a somewhat viscid substance, containing, in addition to carbon, oxygen, and hydrogen, nitrogen, sulphur, and phosphorus."

\section{CIRCULATION OF SAPS.}

"In consideration of the subject of the circulation of saps in the entire plant, two tolics are involved about which there have been much controversy and speculation, and too little observation and true philosophy. The first relates to the ascent of what is styled the crurle sap, which enters at the root and rises against the force of gravitation to the tommost leaf of even the tallest tree. The other has reference to the return of the so-called elaborated sap from the leaf to the root, so as to complete a tree's circulation. Many have said there is no such thing as a general circulation of sap; but no one loubts the fact of an upward flow from the roots, and a vast exhalation of water from the foliage during the period when the vital forces of the plant are active. It is universally admitted that the cells containing chlorophyl are the organs in which the elements of the carbo-hydrates are combined, and from which, therefore, they must pass by some channel to all other parts of the plant, where either. growth occurs, or amyloid substances are stored for future uses." "Whether the albuminoids are formed also in the cells of the leaf, or are the result of combinations occurring in the cambium between the soluble carbo-hydrates and the ingredients of the crude ascending sap, is not certain, and has no necessary connection with the question.")

"Investigation seems to demonstrate that the cambium layer is the seat of life, and that whenever the direct communication between the root and the foliage is cut of in this layer during one entire season of growth, the whole plant perishes. It has also been determined by experiment that if several rings of bark be removed from a growing shoot in such a manner that on one of the isolated sections of bark there be no leaf, while leaves remain on others above and below this, then the leafless section will fail to make any growth in any part. All other sections, if furnisher with one or more healthy learos, will increase in thickness by the formation of new leaves, of wood and bark. This seems to prove that the material for growth is claborated by the leaves, and is transmitted only through the cambium and has 110 power of penetrating the tissues of the wood." 
"The peculiar vital and organic power of the cambium is remarkably illustrated in the structure and growth of grafted trees. Every person is aware that pear trees are grow upon quince roots, and that they often bear finer fruit than when cultivated as standards. This is doubtless owing to the fact that quince roots, being diminutive, furnish less water to the leaves, which thus elaborate a richer sap, and produce more perfectly developed wood and fruit."

"The apricot may be grafted on the plum, and the peach on the apricot, and the almond on the peach, and thus we may produce a tree with plum roots and almond leaves. The wood, however, of the stem, will consist of four distinct varieties, though formed from one continuous cambium layer. Below the almond wood and bark we shall have perfect peach wood and bark, then perfect apricot wood and bark, and at the bottom perfect plum wood and bark. In this curious instance we see the intimate correspondence between the bark and the leaf, for if we should remove the almond branches we might cause the several sorts of wood to develop buds and leafy twigs, each of its own kind. Each section of the compound stem has its seat of life in the cambium, and the cambium of each reproduces cells of its own species out of a common nutrient fluid. Thus there is seen to be a flow of sap upward in the wood and a flow of organizable material, essential to the life of the plant, proceeding from the leaf to the root, through the bark and cambium layer. From this perfected sap the growth of the season is formed, and provision for the beginning of the next season's growth is also stored up, commonly in the root."

As the fact of a rootward flow of elaborated sap is very generally clenied at the present time, it may be well to quote a single line from the edition published in 1870 of the admirable text-book on botany by the late Professor Henfrey, of London, which has been carefully. revised by Dr. Masters. In reference to the subject he says: "The evidence of a descent of elaborated sap is overwhelming."

Want of space prevents copying in full this excellent paper, which should be read by every fruit grower. (See Massachusetts Agricultural Reports, $1873-74$, pages 159 to 204 .)

Of this paper, Professor Agassiz said: "I need not praise what has been said by President Clark now, for the man who can make such investigations, and report them in such a manner, has the reward of his work in himself, and no eulogy of othors can add to his gratification," etc.

\section{CONCLUSION.}

'There are over twenty species of Coccidx (scale insects) found on this coast. The Coccidre, or bark lice, injure the tree by piercing the bark, foliage, or fruit, for the purpose of sucking the sap.

Aphidix.-These insects do mischief by tapping the delicate tissues of plants with their suckers, and by extracting the richest sap. Some of the Aphicles, which belong to the genus Lachmus, do great damage 
to the apple tree. They are well known by the curious white cottony substance which encircles them, and protects them from the air.

Codlin Moth.-Since writing the article on codlin moth, we met an entomologist, who informed us that he had established, beyond doubt, that there is but one brood of the codlin moth in each year; that he had experimented by raising them in his office, etc., and that he considered the matter settled. We heartily wish it were so; but, alas! experiments in the orchards prove our statement correct. We state facts, not fancies. In the matter referred to, we studied nature at its home, and publish the results as truths.

Enterprising fruit growers, the time for sentimentality is past. If your neighbor persists in doing injury to the whole community and State by maintaining a public nuisance (insect pests) in his orchard or premises, and refuses or neglects to do his duty in the matter by taking the necessary steps toward its abatement, report him at once to the Horticultural officer or local Inspector of the district where such orchard and premises are located.

It has been reported from various sections of this State that the larvæ of the codlin moth had been found in the plums, peaches, etc. In the course of our investigations since the Spring of 1877 , we have only found one specimen. In the Spring of 1879 we found a larva of the codlin moth in a peach at Newcastle, Placer County. We think a larva found in the peach, of a smaller species of Tortricidx than the codlin moth, and a larva found in the plum (mistaken by some persons for curculio) are identical. Those larvæ are much smaller than the larvæ of the codlin moth, but otherwise resemble them in appearance; hence the foundation of such reports.

Experiments are being made at the present time by Mr. Kiser, at San José, for destroying scale insects, by covering the tree with a tent, and using steam and other vapors. Also, by Mr. J. H..Wheeler, manufacturer of carbon bisulphide, on citrus trees, at Santa Barbara, using a covering for the tree and applying carbon bisulphide, for destroying the cottony cushion scale, Iceryia purchasi. Reports will be published as soon as received.

The remedies recommended in this work have been properly experimented with, and we know that they have proved effective as insecticides; we also know that they are not injurious to the tree or plant, but beneficial in every sense.

In writing and compiling this work, we have endeavored to present our views in plain language, and have been as sparing as possible in the use of technical scientific terms. We hope, at some future time, to give a more extended description of the insects injurious to fruit and fruit trees in California, and we bespeak for this hastily prepared work the reader's kind indulgence.

Specimens of perfect insects, or their larvæ and pupa, will, at all times be thankfully received at this office.

Respectfully submitted,

MATTHEW COOKE,

Chief Executive Horticultural Officer.

Sacramento, September 30, 1881. 


\section{N D E X.}

Acacia, ete. Scale Insect PAGE.

Aphidæ, Plant-Lice _... .............. 50

Apple Root-Louse ..................... 51

Black Seale_..._.

Borers, Currant, etc................. 25

Caterpillars _...

Caterpillars, C. americana_............. 24

Caterpillars, C. constricta _.............. 22

Caterpillars, 0. leucostigma _............ 24

Codlin Moth ............ 13

Codlin Moth, broods of _.............15, 71

Codlin Moth, in Peaches, Plums, etc..... 71

Codlin Moth, to distinguish Sex.......... 18

Common Apple Scale Inseet ............ 37

Coitony Cushion Scale Insect ........... 38

Cottony Grape Scale Insect .............. 40

Currant Borers _........... 25

Currant Seale Insect......... _........ 41

Ellwood _..._.

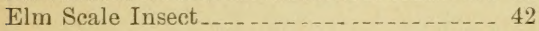

Experiments _..... . . . . . . 55

Fruit Boxes, return 52

Growth, Structure, etc., of Trees

Horticultural Commissioners, County Boards of _.....

Horticultural Commissioners, State Board of. Horticultural Law

Horticulturists should learn

Lye of Wood Ashes ................... 42

Mealy Bug _..._. 40

Natural Remedies _._._.

Norfolk Island Pine Scale Insect........ 41

Nozzles for Spraying Trees _............. 46

Nursery Stock, Scale on _..._. _........ 52

Olive Trees _... 4 . 42

Orchard Property, Damage to .......... 12

Ornamental Trees, Seale, etc. ............ 42

Oyster Shell Bark-Louse__._..._._. . . . 37

Pear Slug _... . .

Pumps _.....
Quarantine, necessity of _...... PAGE.

Red Scale ................. 38

Red Spider . . .

Remedies, Apple and Pear Trees infested by Scale Insects ........ _........... 43

Remedies, Apple Root-Louse ............. 51

Remedies, Black Scale _.................. 44

Remedies, Caterpillars .............23, 24, 25

Remedies, Codlin Moth ................ 16

Remedies, Common Apple Scale Insect.... 37

Remedies, Cottony Cushion Scale Insect.-- 45

Remedies, Cottony Grape Scale Insect..... 45

Remedies, Currant Borers, etc. ........... 27

Remedies, Elm, etc., Trees, Scale Insect... 45

Remedies, Mealy Bug ................... 41

Remedies, Norfolk Island Pine Scale Insect. 41

Remedies, Olive Trees, Black Scale_.....36, 42

Remedies, Ornamental Trees, Scale Insect_ 42

Remedies, Oyster Shell Bark-Louse_...... 37

Remedies, Peach, Plum, etc., Trees, Scale Insects

Remedies, Pear Slug _....... 19

Remedies, Red Scale Insect _.............. 39

Remedies, Red Spider.................... 22

Remedies, San José Scale Insect........... 34

Remedies, Santa Cruz Scale Insect....... 34

Remedies, Saw Fly _................... 21

Remedies, Smut (D.) ..................... 44

Remedies, Soft Orange Scale Insect ....... 36

Remedies, White Scale Insect _.......... 35

Report, Scale Insects, Prof. Comstock ..... 28

Report, Scale Insects, Messrs. Chapin and Vestal

Rules and Regulations recommended..... 11

Saw Fly _... 20

Scale Inseets_...

Smut _...

Soft Orange Scale Insect Structure, ete., of Trees, Col. W. S. Clark _. 64

Tent Caterpillar _.......... 24

Tussock Moth _........ 24

Viticultural Commissioners, State Board of Viticultural Law

White Scale, or Rose Scale, Insect_....... 35

Woolly Aphis ........ 50 



\section{LIBRARY OF CONGRESS}

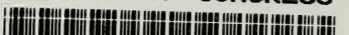

(1)

0 0031623285 